\title{
An integrated approach for distributed energy resource short-term scheduling in smart grids considering realistic power system simulation
}

\author{
M. Silva, H. Morais, Z. Vale \\ GECAD - Knowledge Engineering and Decision Support Research Center - Polytechnic of Porto (IPP), R. Dr. António Bernardino de Almeida, 431, 4200-072 Porto, Portugal
}

\begin{abstract}
The large increase of distributed energy resources, including distributed generation, storage systems and demand response, especially in distribution networks, makes the management of the available resources a more complex and crucial process. With wind based generation gaining relevance, in terms of the gen- eration mix, the fact that wind forecasting accuracy rapidly drops with the increase of the forecast anticipation time requires to undertake short-term and very short-term re-scheduling so the final imple- mented solution enables the lowest possible operation costs. This paper proposes a methodology for energy resource scheduling in smart grids, considering day ahead, hour ahead and five minutes ahead scheduling. The short-term scheduling, undertaken five minutes ahead, takes advantage of the high accuracy of the very-short term wind forecasting providing the user with more efficient scheduling solu-tions. The proposed method uses a Genetic Algorithm based approach for optimization that is able to cope with the hard execution time constraint of short-term scheduling. Realistic power system simula-

tion, based on PSCAD ${ }^{\circledR}$, is used to validate the obtained solutions. The paper includes a case study with

a 33 bus distribution network with high penetration of distributed energy resources implemented in $\operatorname{PSCAD}^{\circledR}$.
\end{abstract}

Keywords:

Distributed energy resources Genetic Algorithm, Network modelingPSCAD, Resource scheduling Simulation, Smart grid

\section{Introduction}

The large increase of Distributed Generation (DG) in Power Systems (PSs) and the introduction of liberalized markets in the electricity sector have caused significant changes in planning and operation of these systems.

A lot of small distributed generation units should be connected to the distribution network in the coming years and this will have significant consequences related to technological and economic matters.

Among DG technologies, especially wind power has already been largely applied but also other technologies are being used, such as hydro small units, photovoltaic units, fuel cell units, cogeneration units and biomass units. Future power systems will have to deal with large-scale integration of DG and other Distributed Energy Resources (DERs), such as storage units and demand response [1]. In the future, it is likely that consumers generate energy with micro generation systems and manage their consumption according to the electricity real-time price, the own generation or in response to the system operator solicitations.

One of the main constraints with renewable energy resources are the dispatchability and reliability problems associated with their operation. The output of some renewable generation, such as wind generators and photovoltaic systems, is determined by the weather conditions and operating patterns will therefore follow these natural conditions. The intermittent nature of these sources leads to an output which often does not suit the load demand profile. This generation intermittence makes network balance and reserve planning more complex than before due to the large number of power input nodes on all voltage levels and bidirectional energy flows between voltage levels.

Therefore, the most important basis for the design of new planning and operation methods is the recognition that distribution networks cannot still be seen as passive networks. Electricity generation and consumption must be measured separately.

The new constraints and the impossibility of accommodating intensive levels of distributed generation with the currently used power systems paradigms led to the smart grid concept. The smart grid can be seen as a digital upgrade of the existing electricity infrastructure to allow dynamic optimization of current operations as well as to incorporate dynamic gateways for alternative sources of energy generation $[2,3]$.

The main characteristics of the smart grid include $[2,3]$ :

- Self-healing - capability to recover from faults and restore the functionality and to operate in islanding mode.

- Fault tolerance - to resist attacks. 


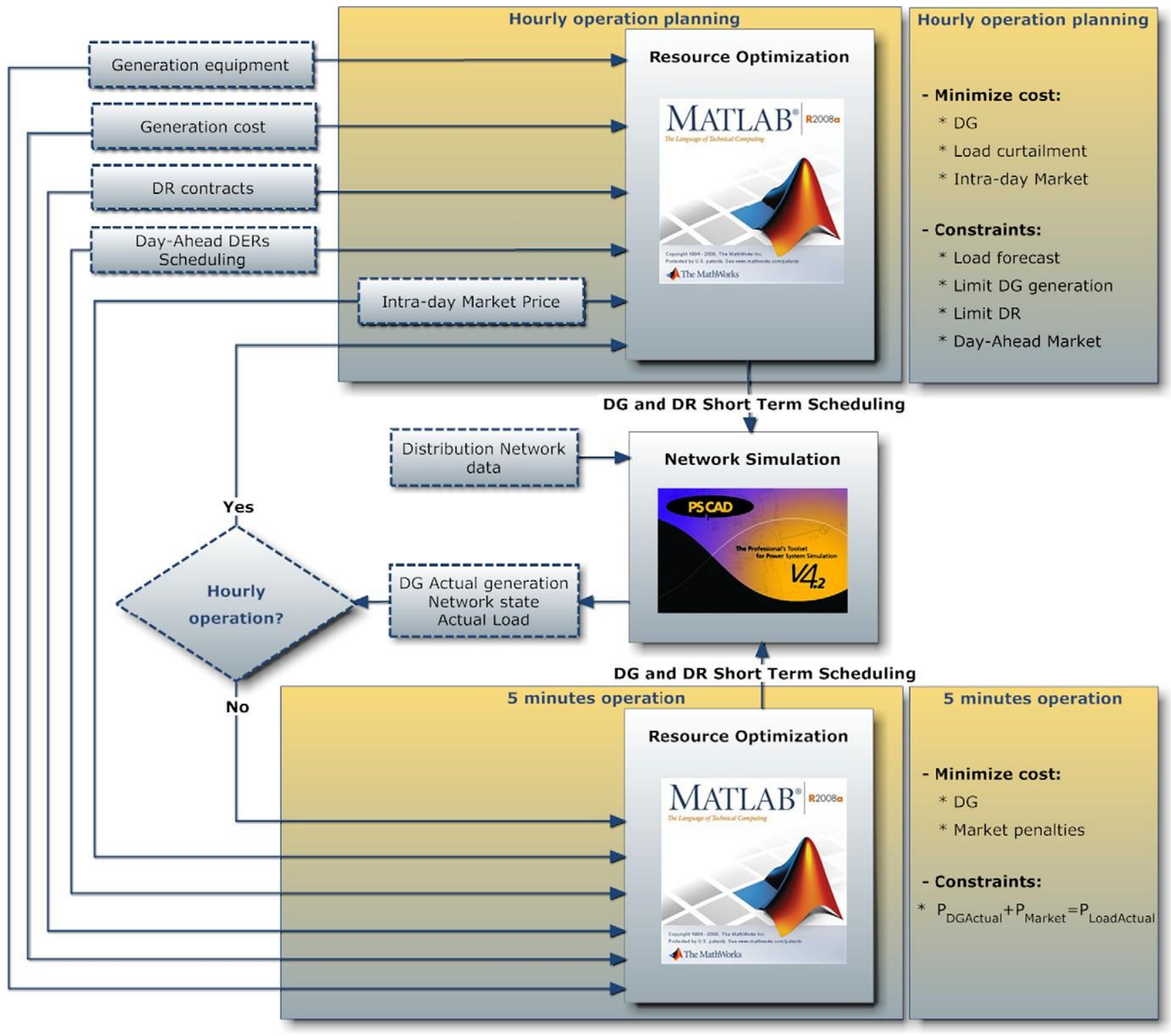

Fig. 1. Proposed methodology schematic diagram.

- Allow the integration of all forms of energy generation and storage options including plug-in vehicles and renewable distributed generation.

- Allow the dynamic optimization of grid operation and resources with full cybersecurity.

- Allow the incorporation of demand-response programs, demand-side resources and energy efficient resources.

- Allow electricity customers to actively participate in the grid operations by providing time information and control options.

- Improve reliability, power quality, security and efficiency of the electricity infrastructure.

Smart grids require a new management philosophy and new operation methods for adequately scheduling renewable based generation and all DER, including the available load curtailment opportunities [4].

In a smart grid context, the large number of players and the aimed distributed decision-making require new management methodologies based on a hierarchized but distributed philosophy. The Independent System Operator (ISO) is at the top level and the lowest levels can include customer control used by consumers to manage their installations according to their own strategy (considering their own generation, and contracts they may have with a Virtual Power Player (VPP)) [5].

Proper use of optimization techniques in the DER short-term scheduling is very relevant for smart grids, because with intensive penetration of DG, storage and load curtailment opportunities enabled by demand response programs, an adequate resource scheduling only can be achieved with little anticipation. This is mainly due to the lack of accuracy in wind forecasting when the forecasting anticipation is increased. In [6] the authors demonstrate that wind forecasting can be very accurate for very short-term forecasting, using the last $5 \mathrm{~h}$ of wind speed data to predict the next $5 \mathrm{~min}$. This methodology can be used in this case to update 5 min ahead optimization input data. In [7] very short-term wind forecasting is also discussed for a real world application using data provided by Hydro Tasmania. A $2.5 \mathrm{~min}$ horizon is proposed in the used neuro-fuzzy methodology with less than $4 \%$ error. However, the forecast accuracy significantly drops when the time horizon is extended, with much higher errors when the prediction is made 
several hours ahead, namely for medium-term forecasting, with over $6 \mathrm{~h}$ of anticipation.

Short-term economic dispatch [8-15] is a very relevant function in modern energy systems. It consists in programming the electric generation correctly in order to reduce the operational cost. Recently, the use of wind power generation and photovoltaic units has significantly increased [16]. Additionally, demand response is currently recognized as a very relevant energy resource that should be considered along with generation and storage resources for cost optimization $[1,17]$.

DER significantly increase the number of variables that must be considered in the economic dispatch problem. Therefore, it is necessary to develop new methodologies to improve the efficiency of economic dispatch methods able to cope with the new paradigms of power systems, namely aiming at obtaining fast response for optimization problems with many variables $[18,19]$. Deterministic optimization techniques require significant computer means and the execution times are not compatible with the short-term scheduling. Therefore, it is necessary to use alternative methodologies, to have fast response for optimization problems with many variables. Computational Intelligence techniques, namely metaheuristics inspired by biological processes, have advantages in terms of computational requirements compared with the traditional optimization techniques. Genetic Algorithms (GAs) are inspired by natural evolution and use concepts such as mutation, selection, and crossover. GA have been successfully used in many power systems problems [20-23].

The authors propose a new methodology to the short-term energy resource management that considers all the referred resources and aims at minimizing the operation costs. The inclusion of demand response events in the DER scheduling and the validation of the solution of the optimization process using a transient simulation tool are relevant contributes of this work. The developed methodology involves resource scheduling with different anticipation times: day-ahead, hour ahead and 5 min ahead. In this way, the most updated forecasted data is used to obtain the best scheduling for the actually available resources. Each resource scheduling considers the previously contracted resources and the new business opportunities.

The solutions that result from the optimization methods must be technically validated using an adequate transient simulation tool. This must be done with realistic models so that simulation results

can be used for the real implementation of the scheduling solutions.

This paper focuses on the short-term energy resource scheduling in a smart grid, considering intensive penetration of DG and oad curtailment opportunities enabled by demand response pro-

grams. The obtained solutions are validated in a simulator that

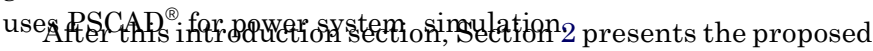

methodology used to implement the short-term energy resource management. Section 3 describes the power system simulation module. Section 4 presents a case study with a $12.66 \mathrm{kV}$ distribution network with 33 buses, 32 loads, 66 DG, with bus 0 connecting to the $60 \mathrm{kV}$ network. Finally, Section 5 presents the most important conclusions of the paper.

\section{Energy resource scheduling}

The proposed DER scheduling method includes the optimization of the currently resources available with three different and successive anticipations: day ahead, hour ahead, and 5 min ahead. This paper focus on the short-term part of this methodology (hour ahead). Day ahead scheduling results are considered as input to the short-term described method which schematic diagram is presented in Fig. 1.
All the resources (generators, storage units, Demand Response (DR) programs, and the intra-day market) are considered by the hour ahead management. The 5 min ahead management only manages the connected generators (regulation up/down and spinning reserve), storage units, and DR with load reduction contracts, and considers eventual market penalties.

Power system simulation is undertaken using the model of the distribution network which has been implemented in $\operatorname{PSCAD}^{\circledR}$ [24]. In each period $\left(5 \mathrm{~min}\right.$ ), the $\mathrm{PSCAD}^{\circledR}$ based network simulation module exports the instant measured data (bus voltages, generation, load consumptions, line power flows, etc.) to the MATLAB ${ }^{\circledR}$ based optimization developed module. The inputs to the optimization algorithms are the actual data of generation and consumption, equipment characteristics, DR contracts, all the previously contracted resources, and electricity market information.

Section 2.1 presents the mathematical formulation of the considered energy resource management problem aiming at minimizing the VPP operation costs. The problem formulation is similar for both used optimization approaches and considers the equipment technical characteristics, envisaged load management actions, and VPP goals.

Section 2.2 presents a Genetic Algorithm (GA) based methodology to obtain the optimal solution for short-term energy resource management.

\subsection{Mathematical formulation}

This sub-section presents the mathematical formulation considering one hour periods, corresponding to the hourly operation planning modeling referred in Fig. 1.

This problem is classified as mixed-integer non-linear. The implementation of this algorithm has been performed on GAMS optimization software. The objective function (1) is formulated with the aim of finding the minimum operation costs in each period $(t)$, usually $1 \mathrm{~h}$, of supplying the demand. Eqs. (2)-(5) refer to the considered constraints that are considered.

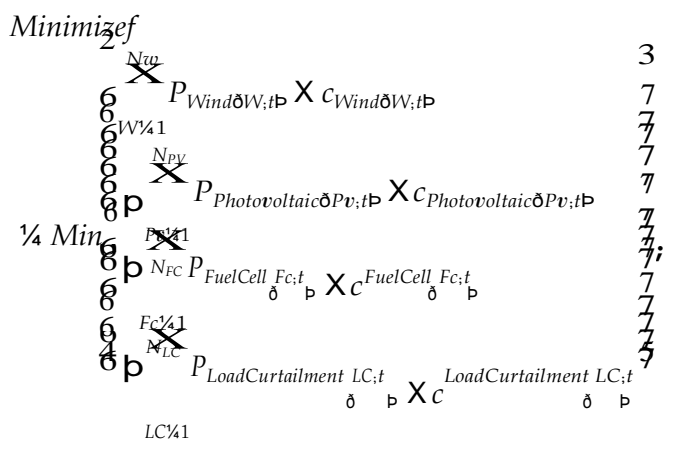

$8 t 2 f 1 ; \ldots ; \mathrm{Tg}$

ð1P

where $c_{\text {FuelCell }(F, t)}$ is the generation cost of fuel cell unit $F_{C}$ in period $t, c_{\text {LoadCurtaiment }(L C, t)}$ the energy cost of load curtailment $L C$ in period $t$, $C_{\text {Photovoltaic }(P v, t)}$ the generation cost of photovoltaic unit $P v$ in period $t$, $c_{\text {Wind }(W, t)}$ the generation cost of wind unit in period $t, N_{F C}$ the number of fuel cells, $N_{L C}$ the number of curtailable loads, $N_{P V}$ the number of photovoltaic panels, $N_{W}$ the number of wind turbines, $P_{\text {Fuel Cell } F c, t)}$ the active power generation of fuel cell unit $F_{c}$ in period $t, P_{\text {LoadCur- }}$ tailment $(L C, t)$ the load curtailment of load $L C$ in period $t, P_{\text {Photovoltaic }(P v, t)}$ the active power generation of photovoltaic unit $P v$ in period $t$, $P_{\text {Wind }(W, t)}$ the active power generation of wind unit $W$ in period $t, t$ the period, and $T$ is the simulation time horizon

subjected to the following constraints:

- Power balance in each period $t$ 


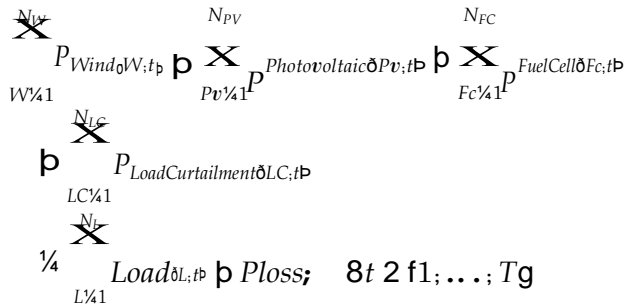

ðр

where $\operatorname{Load}_{(L, t)}$ is the Active power demand of load $L$ in period $t$, Ploss the tqal power losses in distribution lines - calculated through $5 \% \times{ }_{L_{L}^{1 / 41}}^{\text {Load }}$ oLitit , and $N_{L}$ is the number of loads

- Wind generation limits in each period $t$

$P_{\text {WindðW;tp }} 6 P_{\text {WindLimitðW; tp; }} t 2 \mathrm{f} 1 ; \ldots ; T g ; w 2 \mathrm{f} 1 ; \ldots ; N_{W} \mathrm{~g}$

where $P_{\text {Windimit }(W, t)}$ is the maximum active power generation of wind unit $W$ in period $t$.

- Photovoltaic generation limits in each period $t$

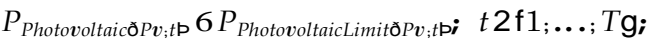

$P \boldsymbol{v} 2 \mathrm{f} 1 ; \ldots ; N_{P V} \mathrm{~g}$

where $P_{\text {Photovoltaiclimit }(P v, t)}$ is the maximum active power generation of photovoltaic unit $P v$ in period $t$

- Fuel cell generation limits in each period $t$

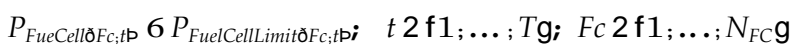

where $P_{\text {FuelCellimit }(F c, t)}$ is the maximum active power generation of fuel cell unit $F_{c}$ in period $t$

\subsection{Genetic Algorithm approach}

The use of meta-heuristics to address optimization problems has several advantages, namely in what concerns the lower processing time when compared with deterministic approaches for solving large dimension complex problems. The authors have already undertaken a comparison study of MINLP and GA approaches to address the energy resource scheduling problem [25]. The GA approach proved to be able to find solutions with costs that are not more than $5 \%$ higher than those found by the MINLP approach. The GA approach presents processing times as lower as $10 \%$ of the ones required by the MINLP approach. This advantage is very relevant to address the short-term scheduling problem considered in the presentpaper.

Genetic Algorithms (GAs) are inspired on genetic biological processes, with the goal of finding the best solution of combinatorial problems. In fact, this type of algorithm cannot guarantee to find the optimal solution but has advantages as it requires less computational resources than traditional approaches [26,27].

The functioning of GAs is broken down into steps of initialization, evaluation, selection, crossover, mutation, update and finalization [28]. Basically, a GA creates a population of possible responses to the problem being treated (initialization) and then submits it to the evolution process constituted by the following steps:

- Evaluation - evaluates the fitness of solutions (individuals of the population) which are analyzed in order to establish how well they respond to the proposed problem.

- Selection - individuals of the population are selected for reproduction. The probability of a given solution being selected is proportional to its fitness.

- Crossover - characteristics of the selected solutions are recombined, generating new individuals.

- Mutation: characteristics of individuals resulting from the process of reproduction are altered, thus adding variety to the population;
- Update: individuals created in this generation are inserted in the population.

- Finalization: checks if the convergence criteria have been achieved. In this case, the execution ends; otherwise it returns to the evaluation stage.

The adequate parameterization of the proposed methodology, such as size of population, number of generations, probability of crossover and type of crossover and mutation, allows finding a balance between the convergence speed and the probability of the process being stuck in local optima.

In this paper, the first step of the optimization process is the input of data concerning the number of the available resources, such as wind turbines, PV panels, fuel cells, and curtailable loads. The

operation limit (for instance the maximum active power generation) and cost for these resources are also inputs of the algorithm.

In order to address the problem considered in this paper, the genes $\left(G_{R_{i}}\right)$ of each GA individual can be of four different types, corresponding to: wind generation, photovoltaic generation, fuel cell generation, and load curtailment. Each individual has 99 genes, corresponding to the 66 DG units, 32 controlled loads, and the supplier from the $60 \mathrm{kV}$ network:

$\left.G_{W_{1}} ; \ldots ; G_{W_{N_{W}}} ; G_{P V_{1}} ; \ldots ; G_{P V_{N_{P V}}} ; G_{F C_{1}} ; \ldots ; G_{F C_{N_{F C}}} ; G_{L C_{1}} ; \ldots ; G_{L C_{N_{L C}}}\right]$

The initial population is obtained through a heuristic method illustrated in Fig. 2 [29]. The method to determine the initial solution consists in choosing the generators that will be connected with the lower costs and the loads that will be cut or reduced. For this purpose let us consider Fig. 2, in which the lines corresponding to the ascending cost of the production generators and to the descending cost of the load curtailment are shown. The method chooses the initial population corresponding to point $\mathrm{A}$ which corresponds to $\operatorname{cost} C$. The chosen point corresponds to a value for the production and load. Using generation and load curtailment merit orders, the scheduled generation units and the curtailed load are determined. The initial population is selected to the minimum cost, and the variables that are associated with this cost are set equal to 1 and the others are initialized as zero.

After setting the initial population, the simulation is performed to reach the final configuration according to the proposed methodology. GA will automatically select the best chromosome at every generation. Thus, at the end of generation the chromosome with the lowest cost is obtained.

To choose the best parameter set, the proposed method has been run 100 times with each considered set of parameters. The choice of the parameters has taken into account the following

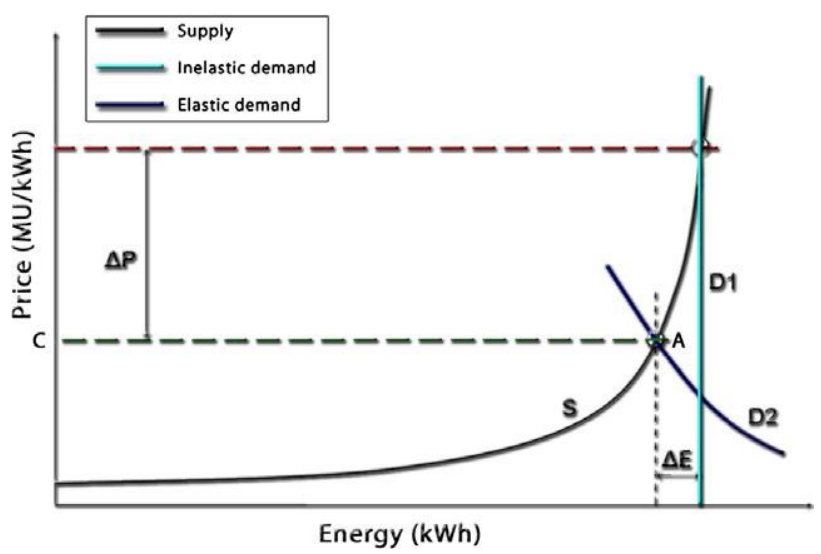

Fig. 2. Chose initial population for each hour based on (adapted from [29]). 
factors: average fitness, maximum fitness, minimum fitness and execution time. Table 1 presents the results for the choice of the GA parameters. More details concerning MATLAB ${ }^{\circledR}$ optimization toolbox parameters can be found in [30].

Each run stopping depends on two criteria: maximum number of generations and maximum time over which the changes in the fitness function are negligible (StallTimeLimit). Fig. 3 shows the fitness function evolution concerning to the case of the set of parameters with the fastest time presented in Table 1.

After a problem sensitivity analysis, the GA parameters used to solve the envisaged short-term scheduling problem are the following:

\begin{tabular}{ll} 
- Size of population: & 30 \\
- Number of generations: & 80 \\
- Fitness scaling: & Proportional \\
- Probability of crossover: & 0.95 \\
- Crossover function: & Heuristic \\
- Mutation function: & Gaussian \\
- Elitism: & 2 chromosomes \\
\hline
\end{tabular}

\section{Short-term scheduling simulator}

In order to improve the efficiency of the use of DER in power systems, it is necessary to create adequate models in simulation tools so that scheduling solutions can be tested before their actual implementation. The work presented in this paper includes the development of a distribution network model, considering intensive penetration of DG units, and the use of a Genetic Algorithm (GA) approach for the short-term energy resources management. MATLAB ${ }^{\circledR}$ is used as the programming environment that supports the developed application which uses $\mathrm{PSCAD}^{\circledR}$ as the network simulation tool.

The choice of these two software packages fulfilled the requirements, providing us with powerful mathematical resources of MATLAB $^{\circledR}$ and with the advantage of an efficient connection with the PSCAD ${ }^{\circledR}$ power system simulator through its FORTRAN interface [31-33]. PSCAD ${ }^{\circledR} /$ EMTDC $^{\text {TM }}$ has been widely used in the study of distributed energy resources [34-39].

To simulate the distribution network for the hourly operation planning, the authors had to implement the network in PSCAD ${ }^{\circledR}$ and to create models of distributed generation units, loads, lines and substation. During the simulation, PSCAD ${ }^{\circledR}$ receives information concerning distribution network data, network state, DG and DR short-term scheduling resulting from the optimization process. The optimization process, executed in MATLAB ${ }^{\circledR}$, needs the following data: generation data, generation costs, DR contracts, dayahead DER scheduling and the intra-day market price, with the objective to minimize the cost of the DG, load curtailment and the intra-day market.

\section{1. $P S C A D^{\circledR}$ model}

As explained above, it is possible to build custom models using PSCAD ${ }^{\circledR}$ Design Editor. Figs. 4-7 show the models used to represent the electricity network, the loads and the distributed generators. The different technologies of production lead to different interfaces with the power system. The interface with the power system plays an important role when considering the operational aspects related to DG. The interfaces considered in this sub-section for the DER models were based on [40,41]. Each component has been modeled and tested independently in $\mathrm{PSCAD}^{\circledR}$, considering the direct connection to an infinite bus. The obtained results were compared with the real equipment is same cases (wind unit and photovoltaic unit), and with theoretical models (small hydro unit, cogeneration unit, waste to energy unit, fuel cell unit and the biomass unit).

Fig. 4 shows the substation model implemented in PSCAD ${ }^{\circledR}$.

The substation model is represented by an infinite bus, the $60 \mathrm{kV}$ transmission line and the substation transformer, which reduces voltage magnitude to the distribution network level.

Loads are modeled in PSCAD ${ }^{\circledR}$ as shown in Fig. 5, by using a resistance and an inductance that are adjusted, taking into account the maximum power demand provided for the simulation period, through the variable control fck shown in Fig. 8.

Fig. 6 shows the distributed generation models implemented in $\operatorname{PSCAD}^{\circledR}$.

For the models that represent the small hydro units, the wind units, the cogeneration units, the waste to energy units, and the biomass units, a rotor synchronous machine with torque control has been used. For each PSCAD component that represents the mentioned technologies, a characteristic curve of torque versus electric power is determined. A block that adjusts the torque of the machine has been created to simulate this curve, according to the variable control fgn provided for the simulation period. The subjacent models consider the generator model and its role for the efficiency of the conversion process; the turbine model is not considered for this work although it can be easily integrated, when available. The characteristic curves are different for each one of these generation technologies.

The distributed generators models remaining, namely for photovoltaic units and fuel cell units, use a controllable current source and a voltage divider. The voltage divider allows the power control, by the measured DC-link voltage, (Uc in Fig. 6), and calculates the magnitude of the controlled current source. These distributed generators are connected to the network through the DC-AC power conversion model represented in Fig. 6.

Fig. 7 shows the distribution line model implemented in PSCAD $^{\circledR}$.

The line model is defined as a line for which the capacitive current effect of capacitive current can be despised. The line is characterized by the resistance and inductive reactance.

Table 1

Choice of GA parameters.

\begin{tabular}{|c|c|c|c|c|c|c|c|c|}
\hline \multicolumn{5}{|c|}{ Parameters GA } & \multicolumn{4}{|l|}{ Results } \\
\hline Population & Generations & \% Crossover & Mutation & Crossover & Time & Mean & Min & $\operatorname{Max}$ \\
\hline 30 & 80 & 0.95 & Heuristic & Gaussian & 48.36 & 39,282 & 39,261 & 39,346 \\
\hline 35 & 100 & 0.93 & Heuristic & Gaussian & 50.32 & 39,278 & 39,269 & 39,262 \\
\hline 30 & 80 & 0.80 & Heuristic & Gaussian & 52.07 & 39,285 & 39,161 & 39,417 \\
\hline 35 & 100 & 0.93 & Two point & Uniform & 60.15 & 39,373 & 39,351 & 39,394 \\
\hline 35 & 100 & 0.93 & Arithmetic & Uniform & 62.33 & 39,374 & 39,370 & 39,377 \\
\hline 35 & 100 & 0.93 & Arithmetic & Adapt feasible & 65.40 & 39,375 & 39,369 & 39,382 \\
\hline 35 & 100 & 0.93 & Two point & Gaussian & 71.58 & 39,288 & 39,264 & 39,362 \\
\hline 100 & 300 & 0.80 & Two point & Uniform & 157.48 & 39,373 & 39,363 & 39,380 \\
\hline
\end{tabular}




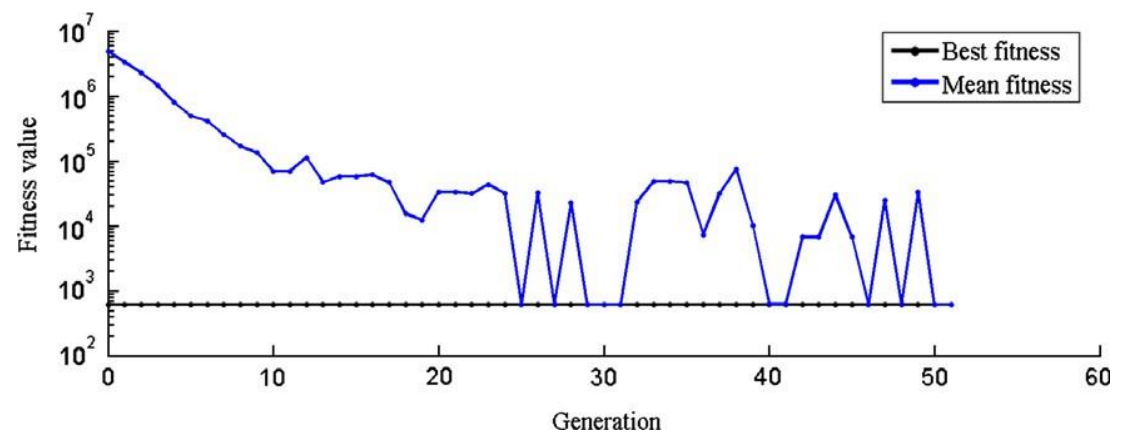

Fig. 3. Fitness function evolution of the proposed methodology in the best value of the period 2 .

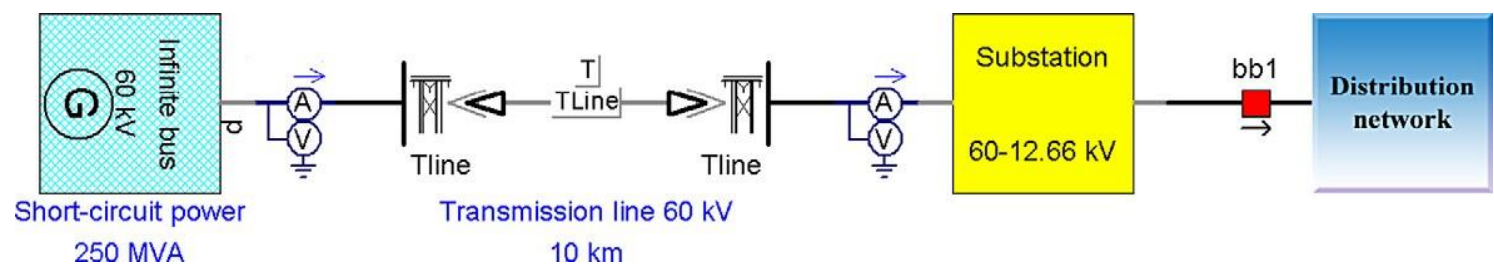

Fig. 4. The distribution substation model implemented in PSCAD ${ }^{\circledR}$.

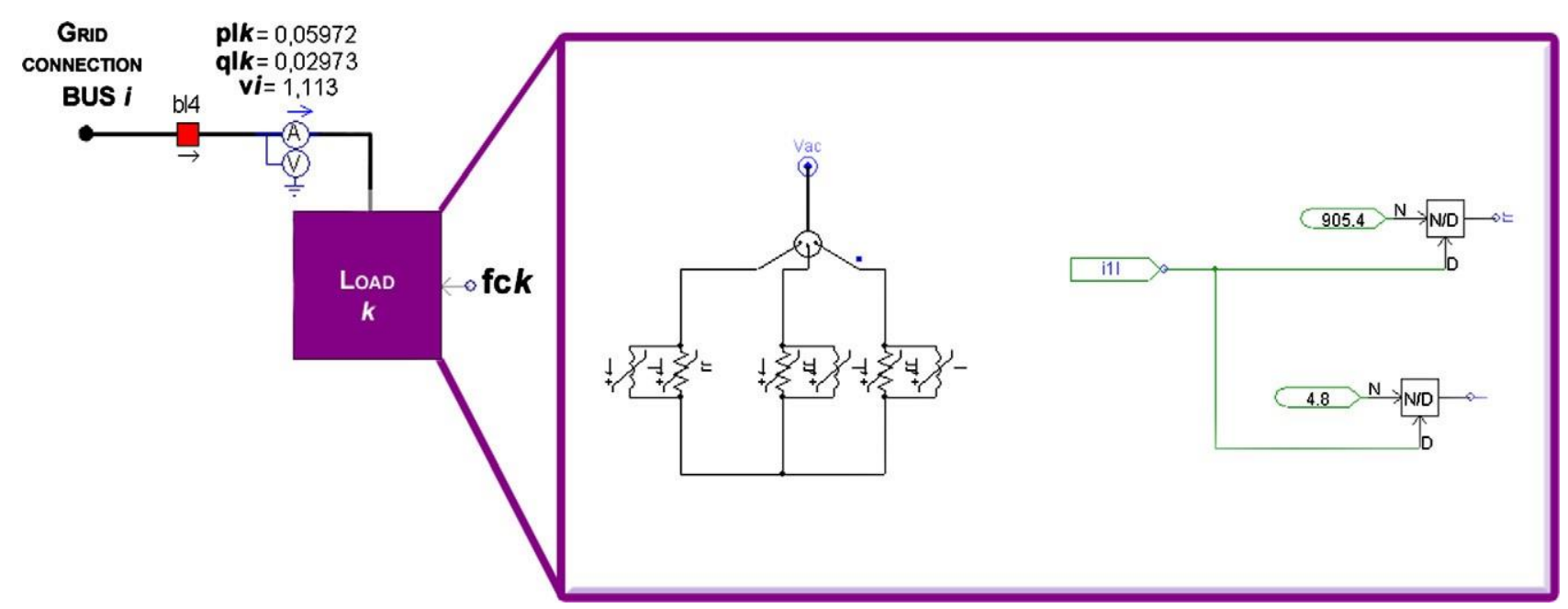

Fig. 5. The load model implemented in PSCAD ${ }^{\circledR}$.

\section{2. $P S C A D^{\circledR}-M A T L A B^{\circledR}$ interface}

$\operatorname{PSCAD}^{\circledR}$ has the capability of interfacing with MATLAB $^{\circledR}$ commands and toolboxes through a special interface. MATLAB $^{\circledR}$ programs or block-sets that are to be interfaced with PSCAD ${ }^{\circledR}$ must be designed and saved as a MATLAB ${ }^{\circledR}$ program file. Then, a userdefined block must be provided in PSCAD ${ }^{\circledR}$, with the necessary inputs and outputs, to interface the MATLAB ${ }^{\circledR}$ file. In this paper, the case study distribution network has been modeled in the PSCAD ${ }^{\circledR}$ EMTDCTM environment. An interfacing block has been created in scripts defined within the block.

Fig. 8 shows components connected to a bus implemented in PSCAD $^{\circledR}$.

The network values obtained for period $t$ and with load forecast and generation forecast for period $t+1$, are important data for optimization process. The obtained optimized solution is sent to
PSCAD $^{\circledR}$, through the following variables: the load control variable in each load, the maximum instantaneous active power in each distributed generation unit, and the generator control variable in each distributed generation unit. These variables will set the new state of the generators and loads.

\section{Case study}

This case study shows the simulation of a distribution network with high DER penetration using PSCAD ${ }^{\circledR}$ simulation tool and MATLAB $^{\circledR}$ to optimize the energy resources usage. The simulator will iterate with the optimization of the Distributed Energy Resources (DERs) short-term scheduling, in terms of the hourly operation planning for a $24 \mathrm{~h}$ scenario. The case study was implemented on the distribution network with 33 buses, from $[42,43]$, as seen in Fig. 9, with load and Distributed Generation (DG) evolution prediction for the year 2040 [44]. This network is connected in bus 


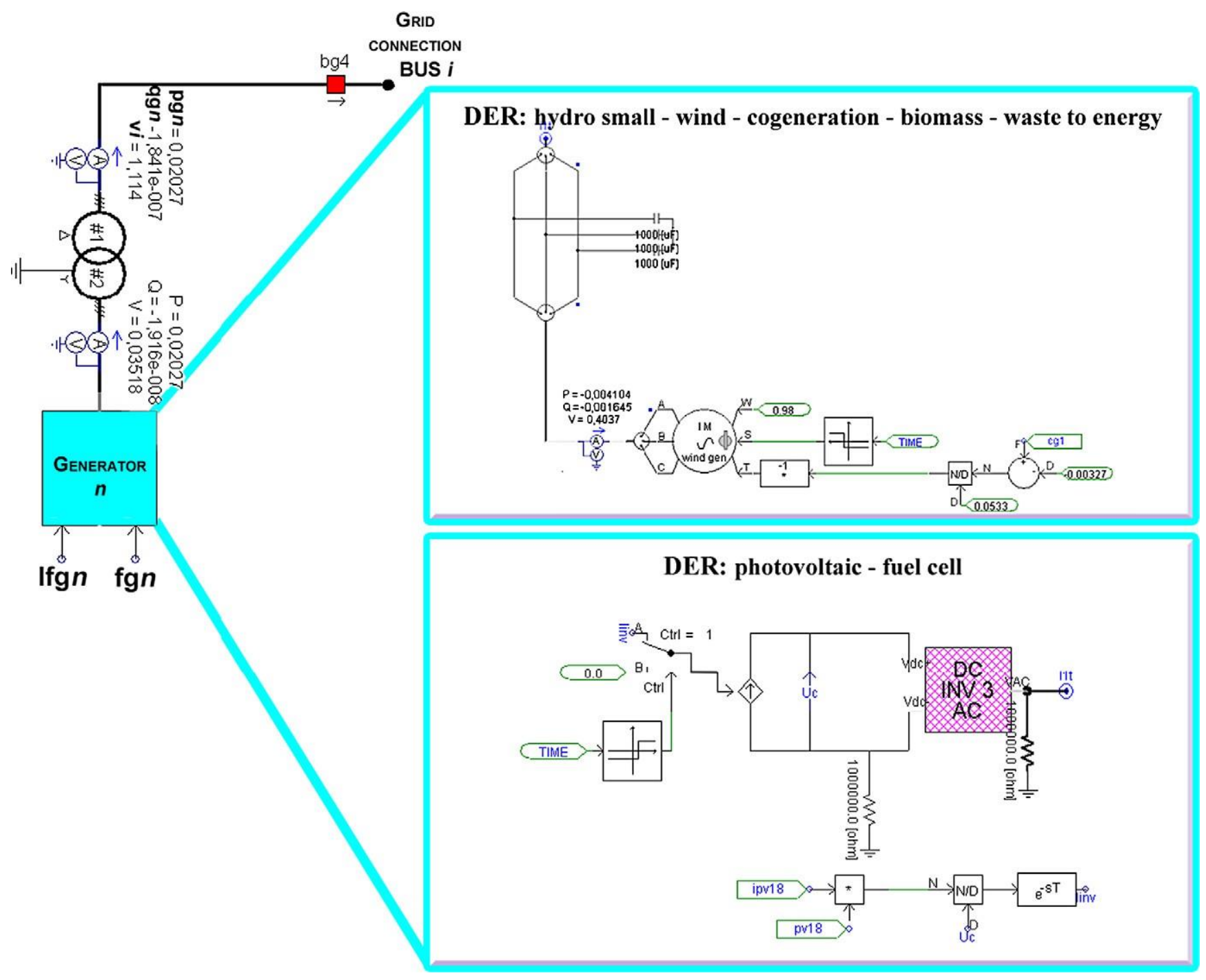

Fig. 6. The distributed generation models implemented in $\operatorname{PSCAD}^{\circledR}$.

0 to the $60 \mathrm{kV}$ network (represented in Fig. 3 with infinite bus and distribution substation).

Table 2 summarizes the considered energy resources costs for the case study and the number of DG units.

The results of evolution prediction of loads consumption and the DG can be seen in Fig. 10.

The Mixed-Integer Non-Linear Programming (MINLP) approach and Genetic Algorithm (GA) based optimization approach described in Section 2 have been used for determining the distributed generation and demand response short-term scheduling for this case study. The method that had the best result (cost vs. runtime) has been simulated in $\operatorname{PSCAD}^{\circledR}$. It is important to note that all 24 optimizations, each one undertaken for one hour, are independent from each other. DER scheduling for period $t$ is undertaken in period $t-1$, considering the operation state resulting from the schedule already used for the previous periods. An important input to the hour ahead problem is the energy resources status and the consumption and generation very-short term forecast. In the present case study, the information about energy resources status are sent by PSCAD ${ }^{\circledR}$ and the forecast of consumption and generation is determined by a specific algorithm presented in [6]. Only with this information and with the information about the day ahead scheduling is possible to do the hour ahead scheduling to period $t$.
The methodology used to simulate the power system of this case study has been tested on a PC compatible with one Intel Xeon W5450 3.00 GHz processor, with 8 Cores, $12 \mathrm{~GB}$ of random-accessmemory (RAM) and Windows Sever Enterprise.

Table 3 shows the results of the DERs scheduling from MINLP.

Table 4 presents the energy total power loss, mean voltage, GA execution time and costs resulting from GA and PSCAD ${ }^{\circledR}$.

The results of the costs described in Tables 3 and 4 are based on Eq. (1) and the cost per $\mathrm{kWh}$ for each generator and load varies according to each period. The minimum and maximum values of the cost (m.u.) are shown in Table 2.

Comparing the results of the proposed methodology based on the GA heuristic, presented in Table 4, with the results of the MINLP approach, presented in Table 3, it is possible to conclude that the difference of operation cost obtained with both methods is less than $10 \%$. On the other hand, processing time is substantially different, with the GA methodology being about $90 \%$ faster than the MINLP methodology. The proposed methodology performance has already been analyzed in [25] for 3 distinct load diagrams scenarios. The GA approach is considered for the methodology proposed in the present paper for realistic power system simulation because the processing time is crucial for short-term scheduling, which is the focus of this paper. 


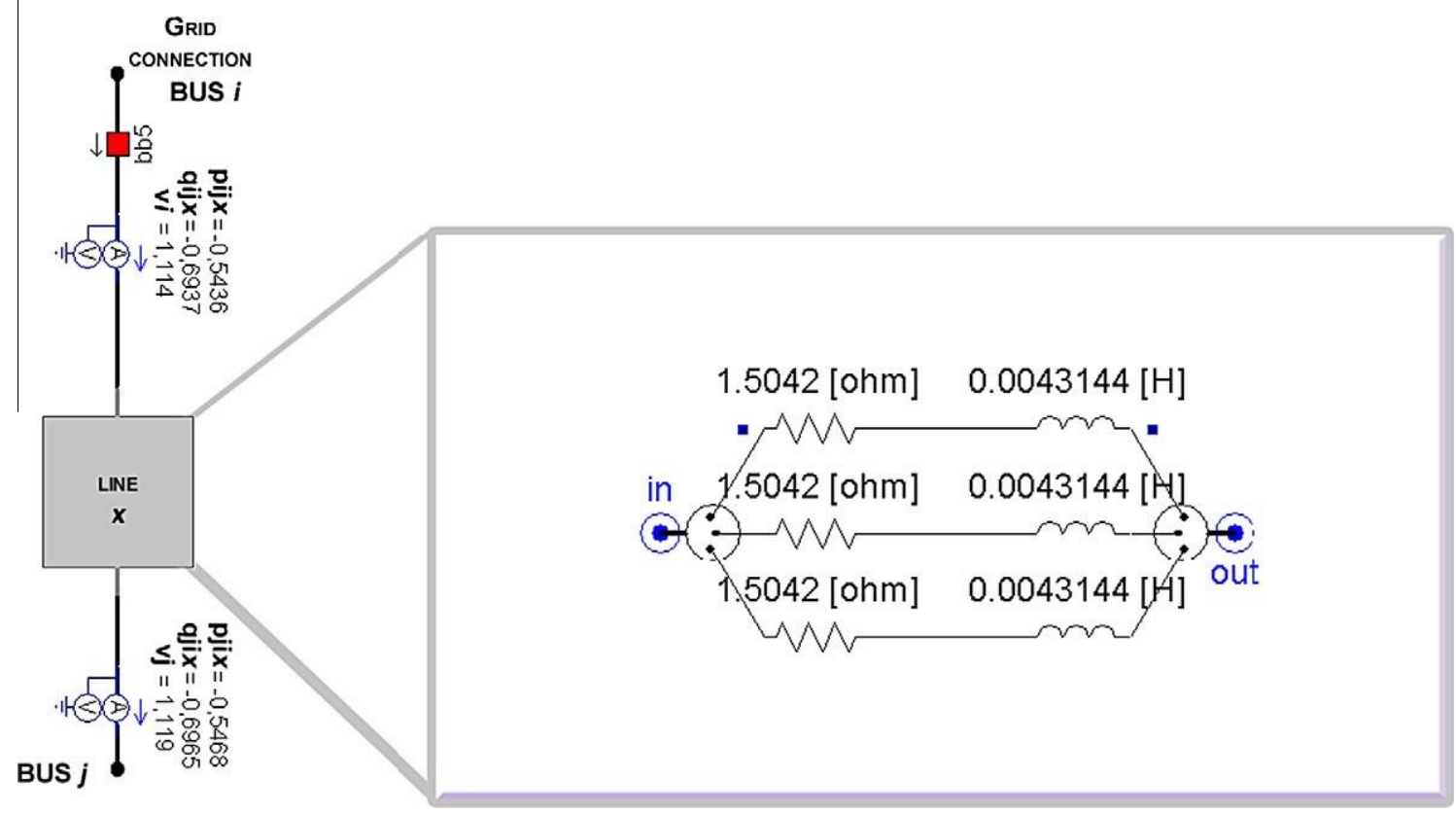

Fig. 7. The distribution line model implemented in $\operatorname{PSCAD}^{\circledR}$.

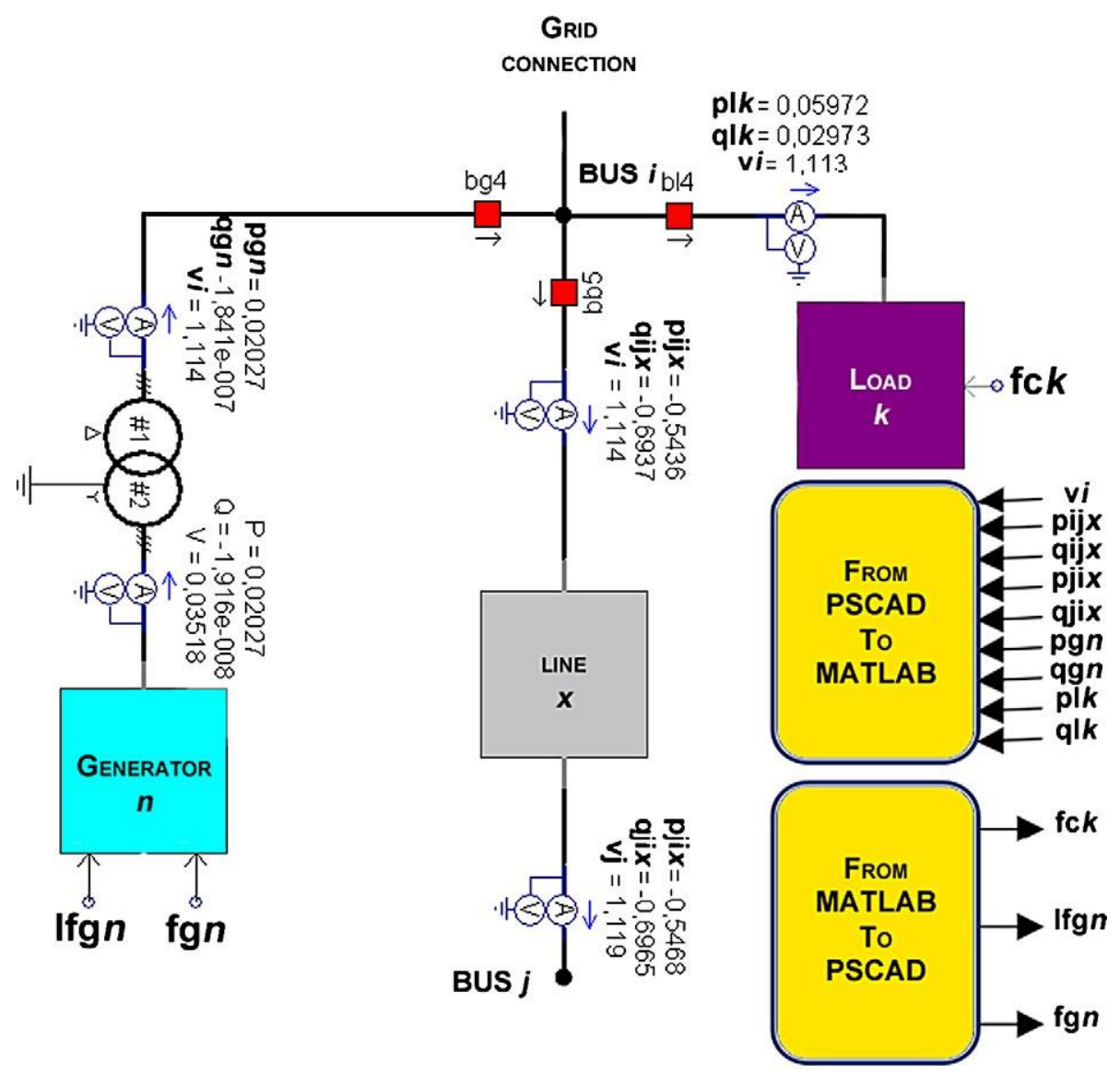

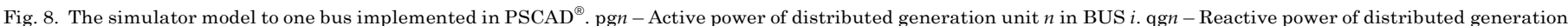

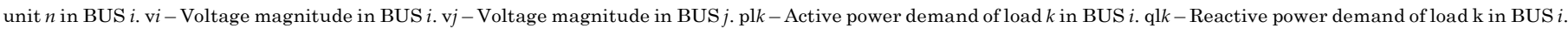

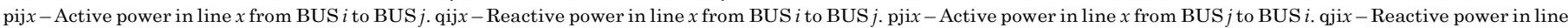

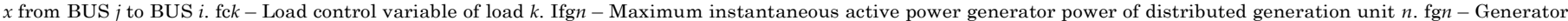
control variable of distributed generation unit $n$. 


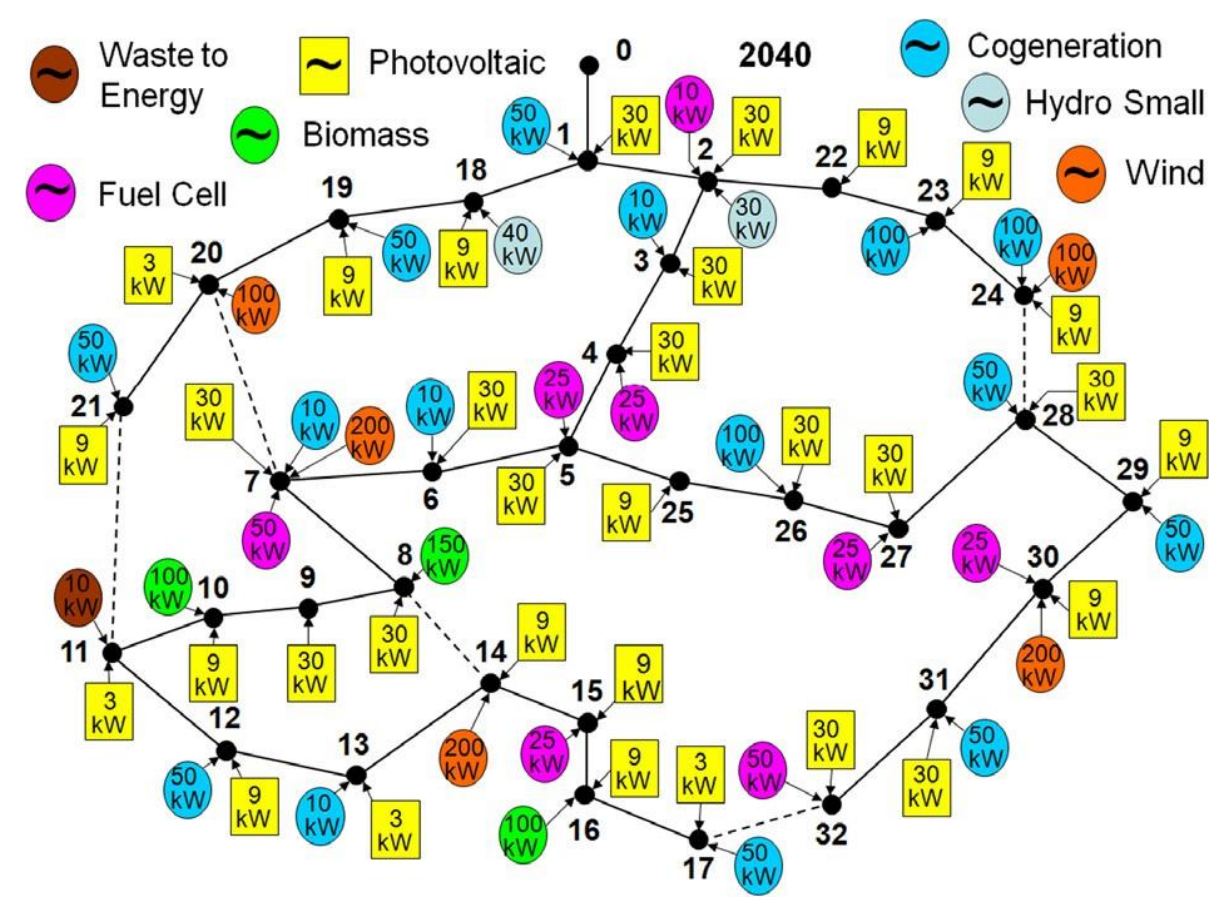

Fig. 9. Bus distribution network configuration in 2040 scenario [44].

Table 2

Case study energy resource data.

\begin{tabular}{lrl}
\hline Energy resources & Number of units & $\begin{array}{l}\text { Maximum/minimum price } \\
\text { Case study }(\mathrm{m} . \mathrm{u} . / \mathrm{kW} \mathrm{h})\end{array}$ \\
\hline Biomass & 3 & $0.30-0.50$ \\
Cogeneration & 15 & $0.30-1.00$ \\
Fuel cell & 8 & $0.40-1.00$ \\
Hydro small & 2 & $0.30-0.50$ \\
Photovoltaic & 32 & $0.30-0.50$ \\
Waste to energy & 1 & $0.30-1.00$ \\
Wind & 5 & $0.30-1.00$ \\
Load & 32 & $1.00-3.00$ \\
Energy supply & 1 & $1.50-3.00$ \\
\hline
\end{tabular}

Analyzing the obtained results presented in Table 4, it is possible to conclude that the difference between the results of GA optimization process and PSCAD ${ }^{\circledR}$ simulation is low. Other important aspect is the processing time of the proposed methodology. The advantage of low run-time will allow reading DER units in real time and implementing the methodology " 5 min ahead" in order to ensure the system balance and stability.

In the presented scenarios the generation is insufficient to supply all the demand, even using the available DR contracts. In this situation, some loads without DR contracts have to be shed, what implies the payment of the corresponding penalties. The obtained results are sent to $\mathrm{PSCAD}^{\circledR}$ where it is possible to analyze the transient effects and the system balance before and after the optimization process.

Let us consider the optimization results for periods 2 and 3 (i.e. hours 2 and 3 of the day considered in this case study) to analyze the transient effects after the optimization process, between two periods. Table 5 shows the results of the DERs scheduling for periods 2 and 3. Table 6 presents the results for the voltage magnitude in distribution network buses, confirming the voltage stability in the system.

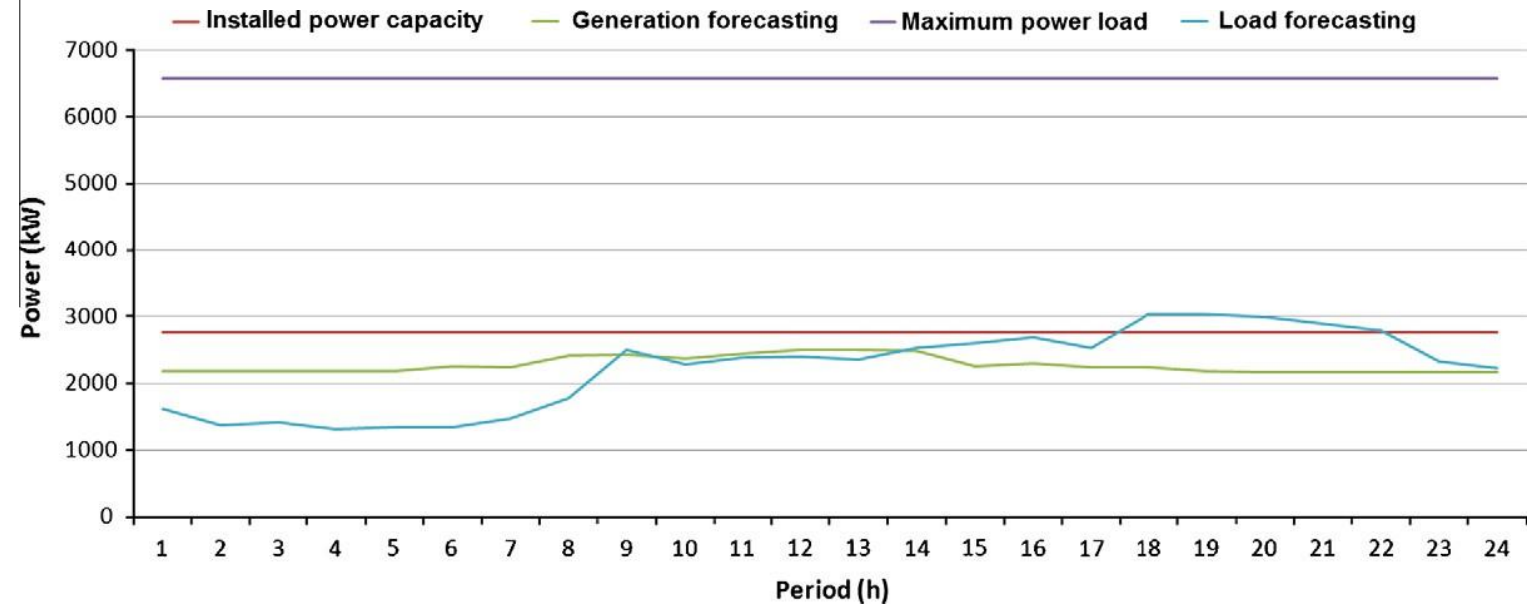

Fig. 10. Load forecasting and the generation forecasting in period $T=24$. 
Table 3

Results scheduling for MINLP.

\begin{tabular}{|c|c|c|c|c|c|c|c|c|c|c|c|c|}
\hline \multirow{2}{*}{$\begin{array}{l}\text { Period } \\
\text { (T) }\end{array}$} & \multicolumn{2}{|l|}{ Load } & \multirow[b]{2}{*}{$\begin{array}{l}\text { Cost } \\
\text { (m.u.) }\end{array}$} & \multicolumn{2}{|c|}{ Generators } & \multirow[b]{2}{*}{$\begin{array}{l}\text { Cost } \\
\text { (m.u.) }\end{array}$} & \multicolumn{2}{|l|}{ Energy supply } & \multirow{2}{*}{$\begin{array}{l}\text { Total power loss } \\
(\mathrm{kW})\end{array}$} & \multirow{2}{*}{$\begin{array}{l}\text { Mean voltage } \\
\text { (p.u.) }\end{array}$} & \multirow{2}{*}{$\begin{array}{l}\text { Execution time } \\
\text { MINLP (s) }\end{array}$} & \multirow{2}{*}{$\begin{array}{l}\text { Total cost } \\
\text { (m.u.) }\end{array}$} \\
\hline & $\begin{array}{l}\text { Forecast } \\
(\mathrm{kW})\end{array}$ & $\begin{array}{l}\text { Schedule by MINLP } \\
(\mathrm{kW})\end{array}$ & & $\begin{array}{l}\text { Forecast } \\
(\mathrm{kW})\end{array}$ & $\begin{array}{l}\text { Schedule by MINLP } \\
(\mathrm{kW})\end{array}$ & & $\begin{array}{l}\text { Schedule by MINLP } \\
\text { (kW) }\end{array}$ & $\begin{array}{l}\text { Cost } \\
\text { (m.u.) }\end{array}$ & & & & \\
\hline 1 & 1619 & 1619 & 0 & 2174 & 1630 & 976 & 0 & 0 & 11.31 & 1.03 & 21.39 & 976 \\
\hline 2 & 1366 & 1366 & 0 & 2174 & 1374 & 668 & 0 & 0 & 7.97 & 1.03 & 20.87 & 668 \\
\hline 3 & 1416 & 1416 & 0 & 2174 & 1425 & 782 & 0 & 0 & 8.63 & 1.03 & 22.32 & 782 \\
\hline 4 & 1315 & 1315 & 0 & 2174 & 1324 & 685 & 0 & 0 & 9.26 & 1.03 & 19.3 & 685 \\
\hline 5 & 1341 & 1341 & 0 & 2174 & 1348 & 722 & 0 & 0 & 7.23 & 1.02 & 20.11 & 722 \\
\hline 6 & 1341 & 1341 & 0 & 2248 & 1351 & 699 & 0 & 0 & 9.89 & 1.03 & 19.16 & 699 \\
\hline 7 & 1467 & 1467 & 0 & 2245 & 1477 & 808 & 0 & 0 & 10.08 & 1.03 & 22.31 & 808 \\
\hline 8 & 1771 & 1771 & 0 & 2415 & 1786 & 1000 & 0 & 0 & 15.02 & 1.03 & 19.12 & 1000 \\
\hline 9 & 2504 & 2414 & 175 & 2423 & 2423 & 1454 & 0 & 0 & 9.10 & 1.03 & 19.44 & 1629 \\
\hline 10 & 2276 & 2255 & 62 & 2367 & 2265 & 1342 & 0 & 0 & 9.65 & 1.03 & 23.11 & 1404 \\
\hline 11 & 2378 & 2305 & 353 & 2444 & 2329 & 1347 & 0 & 0 & 23.53 & 1.03 & 23.06 & 1700 \\
\hline 12 & 2403 & 2403 & 0 & 2502 & 2421 & 1409 & 0 & 0 & 17.84 & 1.03 & 21.55 & 1409 \\
\hline 13 & 2352 & 2352 & 0 & 2505 & 2377 & 1470 & 0 & 0 & 24.65 & 1.03 & 22.69 & 1470 \\
\hline 14 & 2529 & 2473 & 283 & 2485 & 2485 & 1452 & 0 & 0 & 12.15 & 1.03 & 19.56 & 1735 \\
\hline 15 & 2605 & 2221 & 640 & 2247 & 2247 & 1190 & 0 & 0 & 25.45 & 1.03 & 22.91 & 1830 \\
\hline 16 & 2681 & 2266 & 722 & 2291 & 2291 & 1328 & 0 & 0 & 24.75 & 1.03 & 22.42 & 2050 \\
\hline 17 & 2529 & 2217 & 675 & 2242 & 2242 & 1489 & 0 & 0 & 24.78 & 1.03 & 18.63 & 2164 \\
\hline 18 & 3035 & 2230 & 1791 & 2243 & 2243 & 1169 & 0 & 0 & 13.03 & 1.03 & 21.83 & 2960 \\
\hline 19 & 3035 & 2163 & 1679 & 2176 & 2176 & 1388 & 0 & 0 & 12.68 & 1.02 & 21.42 & 3067 \\
\hline 20 & 2985 & 2157 & 1578 & 2170 & 2170 & 1164 & 0 & 0 & 12.73 & 1.03 & 18.96 & 2742 \\
\hline 21 & 2883 & 2145 & 1399 & 2170 & 2170 & 1289 & 0 & 0 & 24.61 & 1.03 & 21.36 & 2688 \\
\hline 22 & 2782 & 2160 & 1242 & 2170 & 2170 & 1189 & 0 & 0 & 10.00 & 1.03 & 19.65 & 2431 \\
\hline 23 & 2327 & 2327 & 0 & 2170 & 2170 & 1307 & 181 & 150 & 23.69 & 1.03 & 21.81 & 1457 \\
\hline 24 & 2226 & 2226 & 0 & 2170 & 2170 & 1166 & 78 & 81 & 21.74 & 1.03 & 20.74 & 1247 \\
\hline Total & & & & & & & & & 369.76 & - & 503.72 & 38,323 \\
\hline
\end{tabular}


Table 4

Results scheduling for GA and PSCAD .

\begin{tabular}{|c|c|c|c|c|c|c|c|c|c|c|c|c|c|c|c|}
\hline \multirow{2}{*}{$\begin{array}{l}\text { Period } \\
\text { (T) }\end{array}$} & \multicolumn{4}{|l|}{ Load } & \multicolumn{4}{|c|}{ Generators } & \multicolumn{3}{|c|}{ Energy supply } & \multirow{2}{*}{$\begin{array}{l}\text { Total power } \\
\text { loss }(\mathrm{kW})\end{array}$} & \multirow{2}{*}{$\begin{array}{l}\text { Mean } \\
\text { voltage } \\
\text { (p.u.) }\end{array}$} & \multirow{2}{*}{$\begin{array}{l}\text { Execution } \\
\text { time GA (s) }\end{array}$} & \multirow{2}{*}{$\begin{array}{l}\text { Total cost } \\
\text { (m.u.) }\end{array}$} \\
\hline & $\begin{array}{l}\text { Forecast } \\
(\mathrm{kW})\end{array}$ & $\begin{array}{l}\text { Schedule by } \\
\text { GA (kW) }\end{array}$ & $\begin{array}{l}\text { Simulated by } \\
\text { PSCAD }(\mathrm{kW})\end{array}$ & $\begin{array}{l}\text { Cost } \\
\text { (m.u.) }\end{array}$ & $\begin{array}{l}\text { Forecast } \\
(\mathrm{kW})\end{array}$ & $\begin{array}{l}\text { Schedule by } \\
\text { GA }(\mathrm{kW})\end{array}$ & $\begin{array}{l}\text { Simulated by } \\
\text { PSCAD }(\mathrm{kW})\end{array}$ & $\begin{array}{l}\text { Cost } \\
\text { (m.u.) }\end{array}$ & $\begin{array}{l}\text { Schedule by } \\
\text { GA }(\mathrm{kW})\end{array}$ & $\begin{array}{l}\text { Simulated by } \\
\text { PSCAD (kW) }\end{array}$ & $\begin{array}{l}\text { Cost } \\
\text { (m.u.) }\end{array}$ & & & & \\
\hline 1 & 1619 & 1619 & 1636 & 0 & 2174 & 1645 & 1668 & 883 & 0 & -13 & 20 & 19.0 & 1.01 & 1.77 & 903 \\
\hline 2 & 1366 & 1366 & 1392 & 0 & 2174 & 1391 & 1365 & 535 & 0 & 52 & 83 & 24.6 & 1.00 & 1.77 & 618 \\
\hline 3 & 1416 & 1239 & 1263 & 53 & 2174 & 1264 & 1207 & 566 & 0 & 83 & 126 & 26.9 & 1.01 & 1.78 & 745 \\
\hline 4 & 1315 & 1315 & 1339 & 0 & 2174 & 1346 & 1464 & 586 & 0 & -95 & 133 & 30.2 & 1.01 & 1.86 & 719 \\
\hline 5 & 1341 & 1341 & 1361 & 0 & 2174 & 1373 & 1471 & 636 & 0 & -82 & 148 & 28.0 & 1.01 & 1.87 & 784 \\
\hline 6 & 1341 & 1341 & 1367 & 0 & 2248 & 1371 & 1501 & 609 & 0 & -104 & 198 & 29.6 & 1.01 & 1.88 & 807 \\
\hline 7 & 1467 & 1467 & 1491 & 0 & 2245 & 1500 & 1605 & 692 & 0 & -88 & 167 & 25.9 & 1.01 & 1.89 & 859 \\
\hline 8 & 1771 & 1771 & 1788 & 0 & 2415 & 1799 & 1860 & 879 & 0 & -52 & 101 & 19.8 & 1.01 & 1.87 & 980 \\
\hline 9 & 2504 & 2403 & 2399 & 196 & 2423 & 2423 & 2382 & 1481 & 0 & 38 & 76 & 21.1 & 1.00 & 1.89 & 1753 \\
\hline 10 & 2276 & 2176 & 2167 & 74 & 2367 & 2303 & 2153 & 1274 & 0 & 27 & 57 & 13.2 & 1.00 & 1.91 & 1405 \\
\hline 11 & 2378 & 2378 & 2384 & 0 & 2444 & 2393 & 2450 & 1612 & 0 & -52 & 117 & 14.5 & 1.00 & 1.89 & 1729 \\
\hline 12 & 2403 & 2398 & 2401 & 55 & 2502 & 2417 & 2525 & 1447 & 0 & -110 & 264 & 14.2 & 1.00 & 2.69 & 1766 \\
\hline 13 & 2352 & 2352 & 2358 & 0 & 2505 & 2366 & 2345 & 1465 & 0 & 26 & 78 & 13.4 & 1.00 & 1.89 & 1543 \\
\hline 14 & 2529 & 2472 & 2364 & 322 & 2485 & 2485 & 2425 & 1371 & 0 & -31 & 87 & 30.4 & 0.97 & 1.90 & 1780 \\
\hline 15 & 2605 & 2209 & 2216 & 648 & 2247 & 2247 & 2125 & 1327 & 0 & 100 & 260 & 9.0 & 1.00 & 2.30 & 2235 \\
\hline 16 & 2681 & 2277 & 2283 & 677 & 2291 & 2291 & 2213 & 1494 & 0 & 86 & 198 & 15.5 & 1.01 & 3.70 & 2369 \\
\hline 17 & 2529 & 2226 & 2239 & 555 & 2242 & 2242 & 2268 & 1576 & 0 & -12 & 26 & 16.7 & 1.01 & 1.90 & 2157 \\
\hline 18 & 3035 & 2226 & 2133 & 1757 & 2243 & 2243 & 2214 & 1502 & 0 & -62 & 174 & 19.1 & 0.98 & 1.90 & 3433 \\
\hline 19 & 3035 & 2156 & 2202 & 1522 & 2176 & 2176 & 2223 & 1556 & 0 & 24 & 72 & 44.7 & 1.02 & 1.93 & 3150 \\
\hline 20 & 2985 & 2125 & 2174 & 1499 & 2170 & 2170 & 2122 & 1355 & 0 & 91 & 282 & 38.8 & 1.02 & 3.51 & 3136 \\
\hline 21 & 2883 & 2131 & 2144 & 1431 & 2170 & 2170 & 2205 & 1471 & 0 & -38 & 99 & 22.6 & 1.01 & 1.92 & 3001 \\
\hline 22 & 2782 & 2147 & 2202 & 1092 & 2170 & 2170 & 2305 & 1409 & 0 & -65 & 143 & 38.4 & 1.02 & 1.81 & 2644 \\
\hline 23 & 2327 & 2139 & 2159 & 327 & 2170 & 2170 & 2150 & 1517 & 0 & 29 & 46 & 20.1 & 1.01 & 1.83 & 1890 \\
\hline 24 & 2226 & 2226 & 2238 & 0 & 2170 & 2170 & 2182 & 1365 & 76 & 73 & 110 & 16.6 & 1.01 & 1.81 & 1475 \\
\hline Total & & & & & & & & & & & & 552.3 & - & 49.47 & 41,881 \\
\hline
\end{tabular}


Table 5

Results scheduling DERs in periods 2 and $3-$ PSCAD $^{\circledR}$.

\begin{tabular}{|c|c|c|c|c|c|c|c|}
\hline \multirow[t]{2}{*}{ Bus no. } & \multirow[t]{2}{*}{ DERs } & \multicolumn{2}{|c|}{ Simulated by PSCAD $(\mathrm{kW})$} & \multirow[t]{2}{*}{ Bus no. } & \multirow[t]{2}{*}{ DERs } & \multicolumn{2}{|c|}{ Simulated by PSCAD $(\mathrm{kW})$} \\
\hline & & Period 2 & Period 3 & & & Period 2 & Period 3 \\
\hline \multirow[t]{3}{*}{1} & Photovoltaic & 0 & 0 & 17 & Photovoltaic & 0 & 0 \\
\hline & Cogeneration & 0 & 0 & & Cogeneration & 0 & 0 \\
\hline & Load 1 & 43 & 37 & & Load 17 & 33 & 34 \\
\hline \multirow[t]{3}{*}{2} & Fuel cell + photovoltaic & 20 & 20 & 18 & Hydro small & 40 & 40 \\
\hline & Hydro small & 30 & 30 & & Photovoltaic & 0 & 0 \\
\hline & Load 2 & 33 & 34 & & Load 18 & 33 & 34 \\
\hline \multirow[t]{3}{*}{3} & Cogeneration & 0 & 10 & 19 & Cogeneration & 50 & 50 \\
\hline & Photovoltaic & 0 & 0 & & Photovoltaic & 0 & 0 \\
\hline & Load 3 & 45 & 45 & & Load 19 & 33 & 34 \\
\hline \multirow[t]{2}{*}{4} & Fuel cell + photovoltaic & 0 & 0 & 20 & Photovoltaic & 0 & 0 \\
\hline & Load 4 & 23 & 22 & & Wind & 0 & 0 \\
\hline \multirow[t]{2}{*}{5} & Fuel cell + Photovoltaic & 20 & 0 & & Load 20 & 33 & 34 \\
\hline & Load 5 & 23 & 22 & 21 & Cogeneration & 50 & 50 \\
\hline \multirow[t]{3}{*}{6} & Photovoltaic & 0 & 0 & & Photovoltaic & 0 & 0 \\
\hline & Cogeneration & 10 & 0 & & Load 21 & 34 & 34 \\
\hline & Load 6 & 74 & 76 & 22 & Photovoltaic & 0 & 0 \\
\hline \multirow[t]{4}{*}{7} & Cogeneration & 10 & 10 & & Load 22 & 35 & 34 \\
\hline & Fuel cell + photovoltaic & 40 & 0 & 23 & Photovoltaic & 0 & 0 \\
\hline & Wind & 0 & 200 & & Cogeneration & 100 & 0 \\
\hline & Load 7 & 75 & 76 & & Load 23 & 154 & 160 \\
\hline \multirow[t]{3}{*}{8} & Photovoltaic & 0 & 0 & 24 & Photovoltaic & 0 & 0 \\
\hline & Biomass & 150 & 150 & & Cogeneration & 100 & 0 \\
\hline & Load 8 & 23 & 22 & & Wind & 0 & 86 \\
\hline \multirow[t]{2}{*}{9} & Photovoltaic & 0 & 0 & & Load 24 & 155 & 160 \\
\hline & Load 9 & 23 & 22 & 25 & Photovoltaic & 0 & 0 \\
\hline \multirow[t]{3}{*}{10} & Photovoltaic & 0 & 0 & & Load 25 & 22 & 23 \\
\hline & Biomass & 100 & 100 & 26 & Photovoltaic & 0 & 0 \\
\hline & Load 10 & 17 & 17 & & Cogeneration & 100 & 100 \\
\hline \multirow[t]{3}{*}{11} & Waste to energy & 10 & 10 & & Load 26 & 24 & 23 \\
\hline & Photovoltaic & 0 & 0 & 27 & Fuel cell + photovoltaic & 20 & 20 \\
\hline & Load 11 & 23 & 23 & & Load 27 & 22 & 23 \\
\hline \multirow[t]{3}{*}{12} & Cogeneration & 50 & 0 & 28 & Photovoltaic & 0 & 0 \\
\hline & Photovoltaic & 0 & 0 & & Cogeneration & 50 & 0 \\
\hline & Load 12 & 22 & 23 & & Load 28 & 45 & 45 \\
\hline \multirow[t]{3}{*}{13} & Cogeneration & 10 & 0 & 29 & Photovoltaic & 0 & 0 \\
\hline & Photovoltaic & 0 & 0 & & Cogeneration & 50 & 50 \\
\hline & Load 13 & 44 & 16 & & Load 29 & 74 & 76 \\
\hline \multirow[t]{4}{*}{14} & Wind A & 0 & 0 & 30 & Fuel cell + photovoltaic & 20 & 20 \\
\hline & Wind B & 25 & 100 & & Wind & 96 & 0 \\
\hline & Photovoltaic & 0 & 0 & & Load 30 & 57 & 22 \\
\hline & Load 14 & 23 & 23 & 31 & Photovoltaic & 0 & 0 \\
\hline 15 & Fuel cell + photovoltaic & 24 & 24 & & Cogeneration & 50 & 50 \\
\hline & Load 15 & 22 & 23 & & Load 31 & 77 & 0 \\
\hline 16 & Biomass & 100 & 47 & 32 & Fuel cell + photovoltaic & 40 & 40 \\
\hline & Photovoltaic & 0 & 0 & & Load 32 & 27 & 23 \\
\hline & Load 16 & 23 & 23 & & & & \\
\hline & & & & Total & Generators (kW) & 1365 & 1207 \\
\hline & & & & & Load $(\mathrm{kW})$ & 1392 & 1263 \\
\hline
\end{tabular}

Table 6

Results voltage in periods 2 and $3-$ PSCAD $^{\circledR}$

\begin{tabular}{rlrcll}
\hline \multirow{2}{*}{ Bus no. } & \multicolumn{2}{l}{ Voltage (p.u.) } & Busno. & \multicolumn{2}{l}{ Voltage (p.u.) } \\
\cline { 2 - 3 } & Period 2 & Period 3 & & Period 2 & Period 3 \\
\hline 1 & 0.9985 & 1.0016 & 18 & 0.9938 & 0.9989 \\
2 & 0.9945 & 0.9994 & 19 & 0.9943 & 0.9997 \\
3 & 0.9960 & 1.0007 & 20 & 0.9944 & 0.9999 \\
4 & 0.9976 & 1.0022 & 21 & 0.9944 & 0.9999 \\
5 & 1.0021 & 1.0067 & 22 & 0.9934 & 0.9983 \\
6 & 1.0026 & 1.0072 & 23 & 0.9915 & 0.9966 \\
7 & 1.0047 & 1.0081 & 24 & 0.9909 & 0.9957 \\
8 & 1.0071 & 1.0104 & 25 & 1.0026 & 1.0073 \\
9 & 1.0087 & 1.0120 & 26 & 1.0033 & 1.0083 \\
10 & 1.0092 & 1.0124 & 27 & 1.0069 & 1.0130 \\
11 & 1.0096 & 1.0127 & 28 & 1.0098 & 1.0165 \\
12 & 1.0116 & 1.0144 & 29 & 1.0110 & 1.0180 \\
13 & 1.0124 & 1.0150 & 30 & 1.0110 & 1.0184 \\
14 & 1.0131 & 1.0156 & 31 & 1.0108 & 1.0183 \\
15 & 1.0133 & 1.0158 & 32 & 1.0109 & 1.0184 \\
16 & 1.0137 & 1.0164 & & & \\
17 & 1.0137 & 1.0165 & Mean (p.u.) & 1.0038 & 1.0085 \\
\hline
\end{tabular}

Some of results obtained in $\mathrm{PSCAD}^{\circledR}$ from which it was possible to analyze the transient effects and the system balance after the optimization process are shown in Figs. 11-15.

- Bus 1 - load went from $43 \mathrm{~kW}$ in period $2-37 \mathrm{~kW}$ in period 3 :

In Fig. 11 it is possible to see a low decrease of active (pl1) and reactive (ql1) load consumption. The transient effects are irrelevant for the system.

- Bus 1 - voltage magnitude:

The impact of the total load demand decrease in the distribution network causes a voltage increase in bus 1 . The voltage magnitude in bus 1 is higher than 1 p.u. at the end of period 3. The minimum voltage occurs in bus 24 with 0.9957 p.u.

- Line $0-1-$ power flow and losses: 


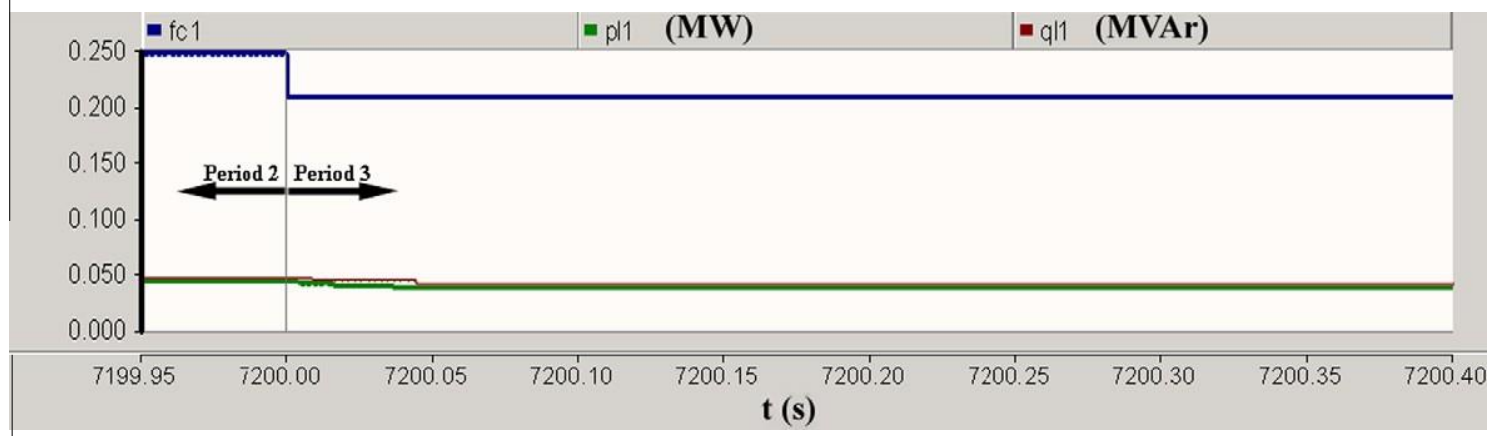

Fig. 11. Active and reactive power consumption in bus 1 .

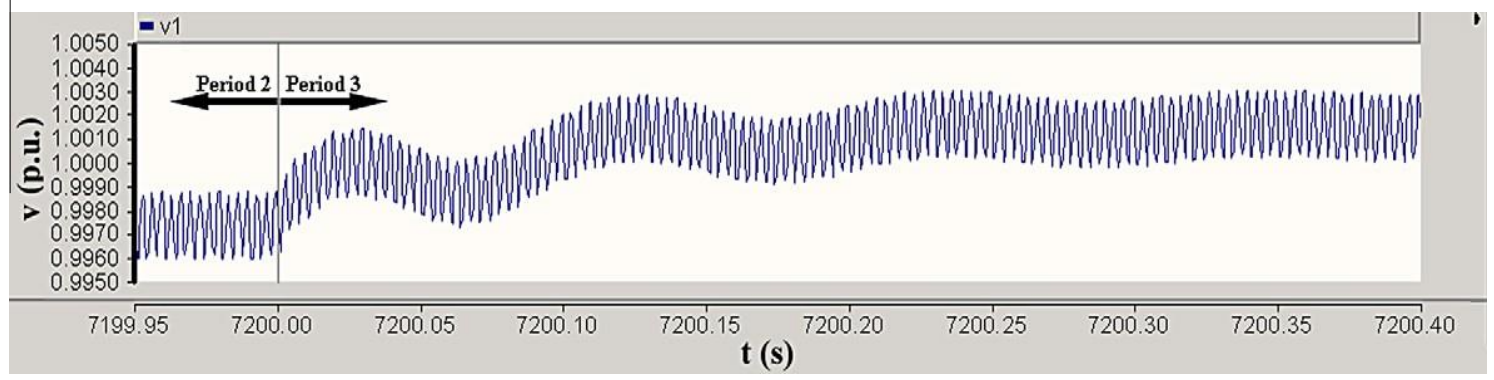

Fig. 12. Bus 1 voltage magnitude.

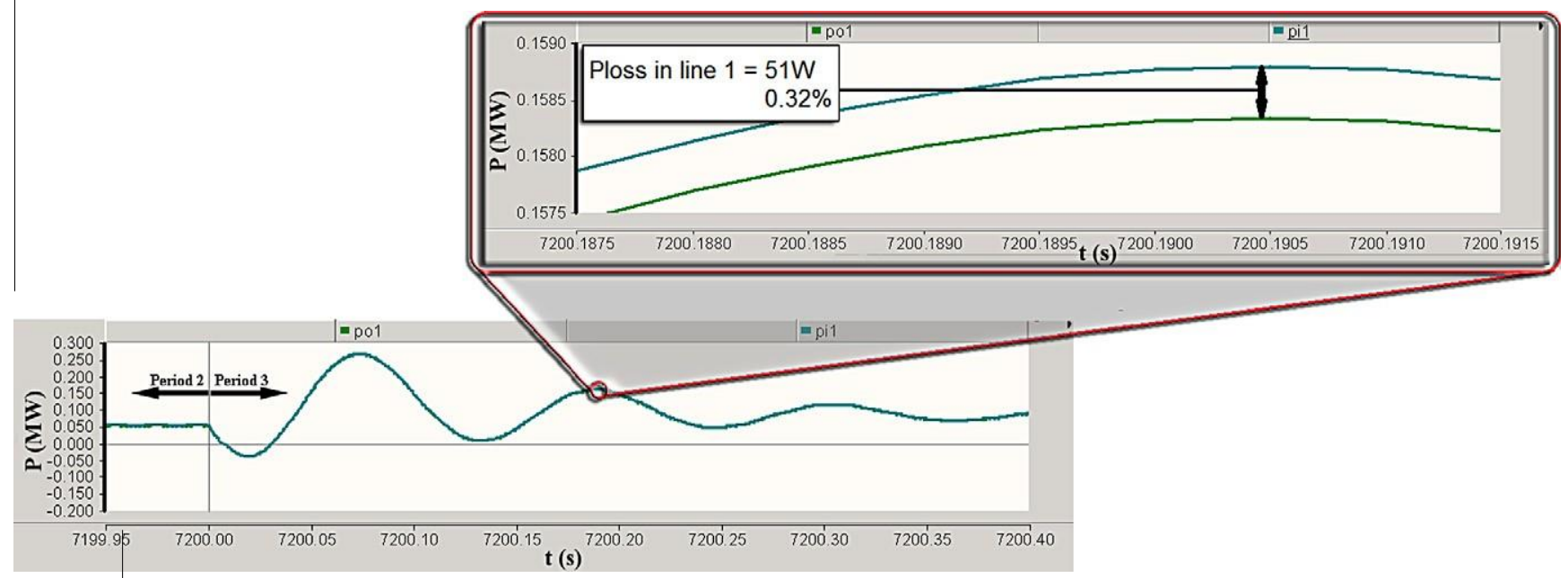

Fig. 13. Power flow and losses in line $0-1$.

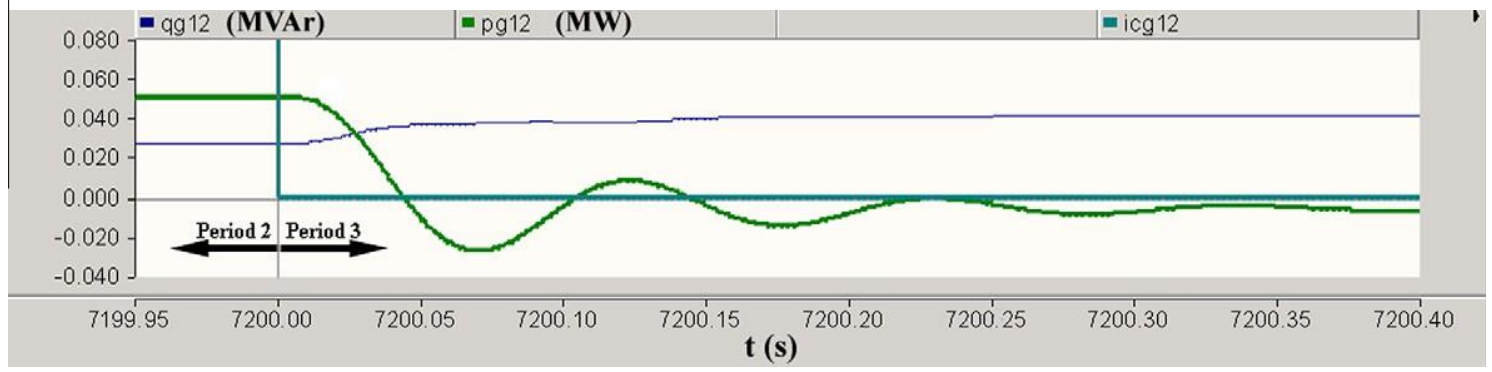

Fig. 14. Active and reactive power generation in CHP, installed in bus 12 .

The power flow in the line between bus 0 and bus 1 increases after the optimization for period 3. Before the optimization process, the power flow is $52 \mathrm{~kW}$ from bus 1 to bus 0 and, after the optimization process, the load flow is $83 \mathrm{~kW}$ in the same 


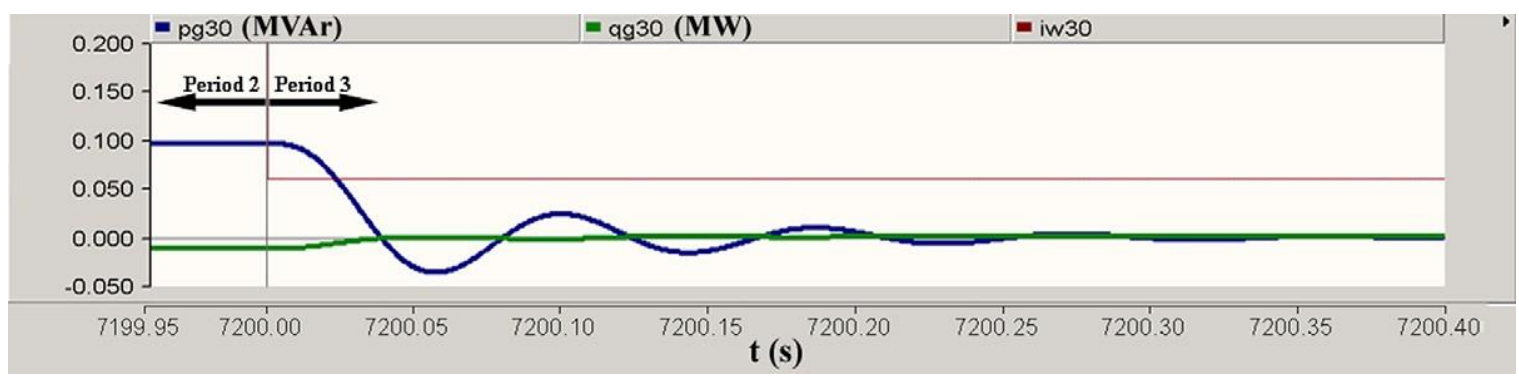

Fig. 15. Active and reactive power generation in Wind, installed in bus 30 .

direction. This increase results from the lower energy price of the external supplier. The power losses in line $0-1$ are equal to $51 \mathrm{~W}$ $(0.32 \%)$

- Bus 12 - the cogeneration unit has been taken out of service:

The active power decrease to zero leads to an oscillation during 1s. With the CHP generator out of service, there is a decrease in the reactive power consumption in bus 12 . As the capacitor bank is kept in service, the corresponding reactive power is injected in the distribution network.

- Bus 30 - wind generator has been taken out of service:

The active power decrease to zero leads to an oscillation during $1.5 \mathrm{~s}$. The reactive power is zero because there are not capacitor banks connected to bus 30 .

- Bus 30 - load went from $57 \mathrm{~kW}$ in period $2-22 \mathrm{~kW}$ in period 3 (Fig. 16):

In order to show the advantages of the proposed methodology with an optimization process, the same process without optimization, that is with all the available DER connected, has been simulated. Table 7 shows the results of the process without optimization.

Analyzing the results presented in Table 4 and in Table 7, it is possible to conclude that the process without optimization results in higher operation costs, with a difference of 9814 m.u. at the end of the 24 periods. Regarding the Total Power Losses there is an increase of $3112 \mathrm{~kW}$ in relation to the optimized process. The power losses values show that implement methodology makes the system operation efficient. At the same time, the obtained lower power flows increase the system reliability and make the eventually required configurations, after incident situations, more efficient than the non optimal ones. Comparing the mean voltages on the buses, the optimization process presents the best results with voltage levels near to $1 \mathrm{p} . \mathrm{u}$.

The proposed method allows to adjust and control remotely the DER in response to the load forecasting, the available generation and the variation in the DER costs and suppliers' price. Its use allows increasing the system efficiency and stability, relieving the operator of the repetitive tasks.

\section{Conclusions}

The present paper proposed a short-term energy resource management methodology for smart grids. This methodology involves day ahead, hour ahead and five minutes ahead scheduling. Shortterm scheduling is used to reschedule the previously obtained schedule taking advantage of the better accuracy of short-term wind forecasting in order to obtain more efficient resource scheduling solutions.

The used optimization is based on a Genetic Algorithm (GA) approach that has proved to achieve a satisfactory cost operating point in a competitive time. The obtained solution feasibility is technically validated using realistic power system simulation. The use of adequate models of the considered generation technologies allows to analyze transient behavior and to adopt adequate implementation plans for the optimal solutions. The proposed method has been implemented using MATLAB $^{\circledR}$ as the programming environment. MATLAB ${ }^{\circledR}$ is connected to PSCAD $^{\circledR}$, allowing improving the potential of both applications and automating the obtained solution analysis.

The case study included in the paper illustrates a 33 bus distribution network with high penetration of renewable generation and consumers with demand response contracts.

The proposed methodology demonstrated to be able to provide users with significant cost reductions, lowering the power losses and resource use costs. Moreover, it includes an automatic analysis of the power system simulation, which is based on the use of PSCAD $^{\circledR}$.

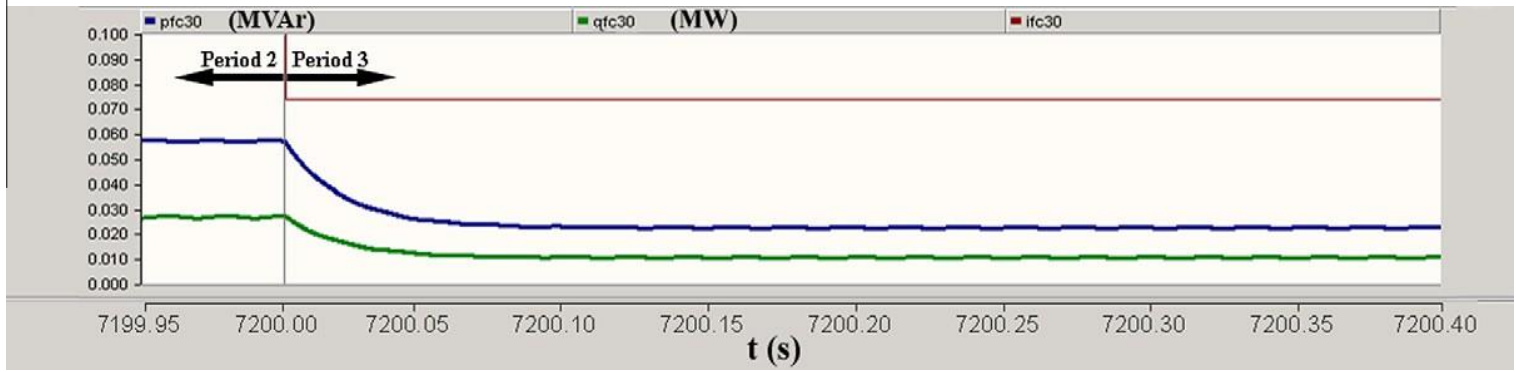

Fig. 16. Active and reactive power consumption in bus 30 . 
Table 7

Results PSCAD ${ }^{\oplus}$ without optimization.

\begin{tabular}{|c|c|c|c|c|c|c|c|c|c|c|c|c|}
\hline \multirow{2}{*}{$\begin{array}{l}\text { Period } \\
\text { (T) }\end{array}$} & \multicolumn{2}{|l|}{ Load } & \multirow[b]{2}{*}{$\begin{array}{l}\text { Cost } \\
\text { (m.u.) }\end{array}$} & \multicolumn{2}{|c|}{ Generators } & \multirow[b]{2}{*}{$\begin{array}{l}\text { Cost } \\
\text { (m.u.) }\end{array}$} & \multicolumn{3}{|c|}{ Energy supply } & \multirow{2}{*}{$\begin{array}{l}\text { Total power loss } \\
(\mathrm{kW})\end{array}$} & \multirow{2}{*}{$\begin{array}{l}\text { Mean voltage } \\
\text { (p.u.) }\end{array}$} & \multirow{2}{*}{$\begin{array}{l}\text { Total cost } \\
\text { (m.u.) }\end{array}$} \\
\hline & $\begin{array}{l}\text { Forecast } \\
(\mathrm{kW})\end{array}$ & $\begin{array}{l}\text { Simulated by PSCAD } \\
(\mathrm{kW})\end{array}$ & & $\begin{array}{l}\text { Forecast } \\
(\mathrm{kW})\end{array}$ & $\begin{array}{l}\text { Simulated by PSCAD } \\
(\mathrm{kW})\end{array}$ & & $\begin{array}{l}\text { Forecast } \\
(\mathrm{kW})\end{array}$ & $\begin{array}{l}\text { Simulated by PSCAD } \\
(\mathrm{kW})\end{array}$ & $\begin{array}{l}\text { Cost } \\
\text { (m.u.) }\end{array}$ & & & \\
\hline 1 & 1619 & 1489 & 0 & 2174 & 2151 & 974 & 0 & -518 & 778 & 143.6 & 0.92 & 1752 \\
\hline 2 & 1366 & 1257 & 0 & 2174 & 2221 & 1037 & 0 & -820 & 1313 & 143.6 & 0.92 & 2350 \\
\hline 3 & 1416 & 1303 & 0 & 2174 & 2196 & 1101 & 0 & -749 & 1124 & 143.6 & 0.92 & 2225 \\
\hline 4 & 1315 & 1210 & 0 & 2174 & 2043 & 1065 & 0 & -689 & 965 & 143.6 & 0.92 & 2030 \\
\hline 5 & 1341 & 1234 & 0 & 2174 & 2153 & 1079 & 0 & -775 & 1396 & 143.6 & 0.92 & 2475 \\
\hline 6 & 1341 & 1234 & 0 & 2248 & 2302 & 1278 & 0 & -925 & 1758 & 143.0 & 0.92 & 3036 \\
\hline 7 & 1467 & 1364 & 0 & 2245 & 2296 & 1245 & 0 & -790 & 1501 & 141.9 & 0.93 & 2746 \\
\hline 8 & 1771 & 1647 & 0 & 2415 & 2387 & 1363 & 0 & -582 & 1135 & 158.0 & 0.93 & 2498 \\
\hline 9 & 2504 & 2329 & 0 & 2423 & 2450 & 1633 & 0 & 50 & 100 & 170.9 & 0.93 & 1733 \\
\hline 10 & 2276 & 2117 & 0 & 2367 & 2322 & 1646 & 0 & -32 & 66 & 173.5 & 0.93 & 1712 \\
\hline 11 & 2378 & 2212 & 0 & 2444 & 2504 & 1344 & 0 & -131 & 301 & 161.1 & 0.93 & 1645 \\
\hline 12 & 2403 & 2235 & 0 & 2502 & 2523 & 1483 & 0 & -121 & 289 & 167.4 & 0.93 & 1772 \\
\hline 13 & 2352 & 2187 & 0 & 2505 & 2520 & 1405 & 0 & -165 & 496 & 167.7 & 0.93 & 1901 \\
\hline 14 & 2529 & 2352 & 0 & 2485 & 2498 & 1209 & 0 & 27 & 76 & 173.2 & 0.93 & 1285 \\
\hline 15 & 2605 & 2423 & 0 & 2247 & 2220 & 1225 & 0 & 375 & 974 & 171.6 & 0.93 & 2199 \\
\hline 16 & 2681 & 2493 & 0 & 2291 & 2315 & 1267 & 0 & 337 & 774 & 158.6 & 0.93 & 2041 \\
\hline 17 & 2529 & 2352 & 0 & 2242 & 2224 & 1011 & 0 & 271 & 595 & 142.5 & 0.93 & 1606 \\
\hline 18 & 3035 & 2823 & 0 & 2243 & 2235 & 1136 & 0 & 731 & 2047 & 143.2 & 0.93 & 3183 \\
\hline 19 & 3035 & 2792 & 0 & 2176 & 2101 & 964 & 0 & 835 & 2505 & 144.0 & 0.92 & 3469 \\
\hline 20 & 2985 & 2746 & 0 & 2170 & 2151 & 1072 & 0 & 741 & 2296 & 145.8 & 0.92 & 3368 \\
\hline 21 & 2883 & 2652 & 0 & 2170 & 2137 & 893 & 0 & 661 & 1718 & 145.8 & 0.92 & 2611 \\
\hline 22 & 2782 & 2559 & 0 & 2170 & 2100 & 1065 & 0 & 605 & 1572 & 145.8 & 0.92 & 2637 \\
\hline 23 & 2327 & 2141 & 0 & 2170 & 2195 & 928 & 0 & 92 & 147 & 145.8 & 0.92 & 1075 \\
\hline 24 & 2226 & 2048 & 0 & 2170 & 2201 & 334 & 0 & -7 & 11 & 145.8 & 0.92 & 345 \\
\hline Total & & & & & & & & & & 3664 & _- & 51,695 \\
\hline
\end{tabular}




\section{Acknowledgements}

This work is supported by FEDER Funds through COMPETE program and by National Funds through FCT under the projects FCOMP-01-0124-FEDER: PEst-OE/EEI/UI0760/2011, PTDC/EEAEEL/099832/2008, and PTDC/SEN-ENR/099844/2008.

\section{References}

[1] Castillo-Cagigal M, Gutiérrez A, Monasterio-Huelin F, Caamaño-Martín E, Masa D, Jiménez-Leube J. A semi-distributed electric demand-side management system with PV generation for self-consumption enhancement. Energy Convers Manage 2011;52:2659-66.

[2] U.S.D.O. Energy. Smart Grid System Report; July 2009

[3] Vale Z, Venayagamoorthy GK, Ferreira J, Morais H. Computational intelligence applications for future power systems. In: Madureira A, Ferreira J, Vale Z, editors. Computational intelligence for engineering systems. Netherlands: Springer; 2011. p. 176-93.

[4] King WDJ, Ozveren CS. Economic load dispatch for a power system with renewable energy using direct search method. In: 2007 42nd International universities power, engineering conference, vol. 1-3; 2007. p. 1228-33.

[5] Morais H, Kadar P, Faria P, Vale ZA, Khodr HM. Optimal scheduling of a renewable micro-grid in an isolated load area using mixed-integer linear programming. Renew Energy 2010;35:151-6.

[6] Ramos S, Soares J, Vale Z, Morais H. A data mining based methodology for wind forecasting. In: 16th International conference on intelligent system applications to power systems (ISAP 2011), Crete, Greece; 2011.

[7] Potter CW, Negnevitsky M. Very short-term wind forecasting for Tasmanian power generation. IEEE Trans Power Syst 2006;21:965-72.

[8] Zhu J. Optimization of power system operation. Piscataway, NJ: Wiley-IEEE Press; 2009.

[9] Huneault M, Galiana FD. A survey of the optimal power flow literature. IEEE Trans Power Syst 1991;6:762-70.

[10] Vlachogiannis JG, Lee KY. Economic load dispatch - a comparative study on heuristic optimization techniques with an improved coordinated aggregationbased PSO. IEEE Trans Power Syst 2009;24:991-1001.

[11] Zhang ZS. Quantum-behaved particle swarm optimization algorithm for economic load dispatch of power system. Exp Syst Appl 2010;37:1800-3.

[12] Dahal KP, Galloway SJ, Aldridge CJ. Developing GA-based hybrid approaches for a real-world mixed-integer scheduling problem. In: The 2003 congress on evolutionary computation, vol. 3 ; 2003. p. 1887-94.

[13] Pappala VS, Erlich I, Rohrig K, Dobschinski J. A stochastic model for the optimal operation of a wind-thermal power system. IEEE Trans Power Syst 2009;24:940-50.

[14] Hong YY, Li CT. Short-term real-power scheduling considering fuzzy factors in an autonomous system using genetic algorithms. Gen Transm Distrib IEE Proc 2006;153:684-92.

[15] Cecati C, Citro C, Piccolo A, Siano P. Smart operation of wind turbines and diesel generators according to economic criteria. IEEE Trans Ind Electroncs 2011;58:4514-25.

[16] Zhang YN, Kang LY, Cao BG, Huang CN, Wu GH. Renewable energy distributed power system with wind power and biogas generator. In: T\&D Asia: 2009 transmission \& distribution conference \& exposition: Asia and Pacific; 2009. p. $74-9$

[17] Palma-Behnke R, Cerda JL, Vargas LS, Jofre A. A distribution company energy acquisition market model with integration of distributed generation and load curtailment options. IEEE Trans Power Syst 2005;20:1718-27.

[18] Vale Z, Morais H, Ramos C, Khodr H, Faria P. Energy resources management for more sustainable distribution systems: an intelligent approach. In: CIRED 2010. Lyon; 2010.

[19] Vale ZA, Morais H, Khodr H, Canizes B, Soares J. Technical and economic resources management in smart grids using heuristic optimization methods. IEEE Power Energy Soc Gen 2010.
[20] Cabello JM, Cejudo JM, Luque M, Ruiz F, Deb K, Tewari R. Optimization of the size of a solar thermal electricity plant by means of genetic algorithms. Renew Energy 2011;36:3146-53.

[21] Kumar VS, Mohan MR. A genetic algorithm solution to the optimal short-term hydrothermal scheduling. Int J Elect Power 2011;33:827-35.

[22] Singh D, Singh D, Verma KS. Multiobjective optimization for DG planning with load models. IEEE Trans Power Syst 2009;24:427-36.

[23] Chen C, Duan S, Cai T, Liu B, Hu G. Smart energy management system for optimal microgrid economic operation. Renew Power Gen, IET 2011;5:258 67.

[24] PSCAD. Applications of PSCAD/EMTDC. Manitoba HVDC Research Centre Inc 2008.

[25] Silva M, Morais H, Vale Z. Distribution network short term scheduling in smart grid context. In: IEEE power and energy society general meeting 2011, Detroit, Michigan, USA; 2011.

[26] Mitchell MP. An introduction to genetic algorithms. Cambridge (Mass), London: MIT; 1996.

[27] Sivanandam SN, Deepa SN. Introduction to genetic algorithms. Berlin: Springer;2008.

[28] Pain AR, Reeves CR. Genetic algorithm optimization software class libraries. In: Voß S, Woodruff DL, editors. Optimization software class libraries. US: Springer; 2002. p. 295-329.

[29] Thimmapuram PR, Jinho K, Botterud A, Youngwoo N. Modeling and simulation of price elasticity of demand using an agent-based model. In: Innovative smart grid technologies (ISGT); 2010. p. 1-8.

[30] MATLAB. Genetic algorithm and direct search toolbox 2 user's guide. The Mathworks, Inc.; 2007.

[31] Cole AM, Denchenko P, Kell DB, Irwin GD. Integrating electromagnetic transient simulation with other design tools. In: Int Conf Power System Transients; 1999.

[32] Cole AM, Daneshpooy A. Towards open systems: a PSCAD/EMTDC to MATLAB interface. In: Int Conf Power System Transients; 1997.

[33] Filizadeh S, Heidari M, Mehrizi-Sani A, Jatskevich J, Martinez JA. Techniques for interfacing electromagnetic transient simulation programs with genera mathematical tools IEEE taskforce on interfacing techniques for simulation tools. IEEE Trans Power Deliv 2008;23:2610-22.

[34] Vinothkumar K, Selvan MP. Novel scheme for enhancement of fault ridethrough capability of doubly fed induction generator based wind farms. Energ Convers Manage 2011;52:2651-8.

[35] Muyeen SM, Al-Durra A, Tamura J. Variable speed wind turbine generator system with current controlled voltage source inverter. Energ Convers Manage 2011;52:2688-94.

[36] Yu IK, Park M, Lee DH. PSCAD/EMTDC modeling and simulation of solarpowered hydrogen production system. Renew Energy 2006;31:2342-55.

[37] Kim SK, Jeon JH, Cho CH, Kim ES, Ahn JB. Modeling and simulation of a gridconnected PV generation system for electromagnetic transient analysis. Sol Energy 2009;83:664-78.

[38] Wong JH, Lim YS, Taylor P, Morris S. Optimal utilisation of small-scale embedded generators in a developing country - a case study in Malaysia. Renew Energy 2011;36:2562-72.

[39] Babaei E, Farhadi Kangarlu M. Operation and control of dynamic voltage restorer using single-phase direct converter. Energy Convers Manage 2011;52:2965-72.

[40] Glover JD, Sarma MS, Overbye TJ. Power system analysis and design, 4th ed. In International student (Ed.), Thomson, Southbank, Vic. London; 2008.

[41] Mossey P. The first five years: dawn of a new era? Brit Dent J 2003;194:350-1.

[42] Baran ME, Wu FF. Network reconfiguration in distribution-systems for loss reduction and load balancing. IEEE Trans Power Deliv 1989;4:1401-7.

[43] Faria P, Vale Z, Soares J, Ferreira J. Demand response management in power systems using a particle swarm optimization approach. Intell Syst, IEEE; in press [Corrected Proof]. http://doi.ieeecomputersociety.org/10.1109/ MIS.2011.35.

[44] Faria P, Vale ZA, Ferreira J. Demsi - a demand response simulator in the context of intensive use of distributed generation. In: IEEE international conference on systems man and cybernetics (SMC), 2010; 2010. p. 202532 . 